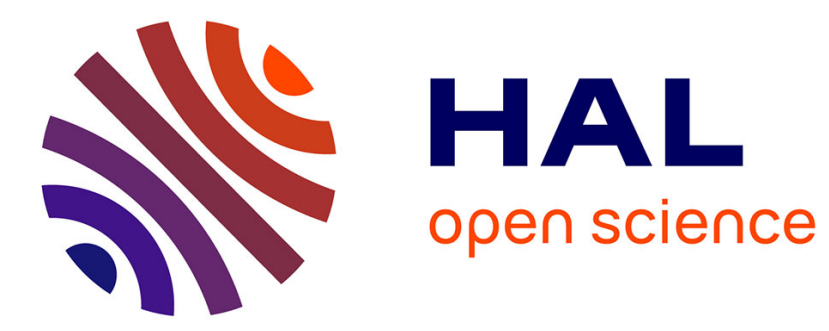

\title{
An agent-based model of trickle-up growth and income inequality
}

Elisa Palagi, Mauro Napoletano, Andrea Roventini, Jean-Luc Gaffard

\section{To cite this version:}

Elisa Palagi, Mauro Napoletano, Andrea Roventini, Jean-Luc Gaffard. An agent-based model of trickle-up growth and income inequality. 2021. hal-03373193

\section{HAL Id: hal-03373193 \\ https://hal-sciencespo.archives-ouvertes.fr/hal-03373193}

Preprint submitted on 11 Oct 2021

HAL is a multi-disciplinary open access archive for the deposit and dissemination of scientific research documents, whether they are published or not. The documents may come from teaching and research institutions in France or abroad, or from public or private research centers.
L'archive ouverte pluridisciplinaire HAL, est destinée au dépôt et à la diffusion de documents scientifiques de niveau recherche, publiés ou non, émanant des établissements d'enseignement et de recherche français ou étrangers, des laboratoires publics ou privés. 


\section{SciencesPo}

\section{AN AGENT-BASED MODEL OF TRICKLE-UP GROWTH AND INCOME INEQUALITY}

Elisa Palagi

Mauro Napoletano

Andrea Roventini

Jean-Luc Gaffard 


\title{
ofce
}

\section{SciencesPo}

\author{
EDITORIAL BOARD
}

Chair: Xavier Ragot (Sciences Po, OFCE)

Members: Jérôme Creel (Sciences Po, OFCE), Eric Heyer (Sciences Po, OFCE), Sarah Guillou (Sciences Po, OFCE), Xavier Timbeau (Sciences Po, OFCE)

\section{CONTACT US}

OFCE

10 place de Catalogne | 75014 Paris | France

Tél. +33144185424

www.ofce.fr

This Working Paper:

Elisa Palagi, Mauro Napoletano, Andrea Roventini and Jean-Luc Gaffard

An agent-based model of trickle-up growth and income inequality Sciences Po OFCE Working Paper, n 19/2021.

Downloaded from URL: www.ofce.sciences-po.fr/pdf/dtravail/WP2021-19.pdf

DOI - ISSN 
ABOUT THE AUTHORS

Elisa Palagi, Institute of Economics and EMbeDS, Scuola Superiore Sant'Anna, Pisa, Italy.

Email Address: elisa.palagi@santannapisa.it

Mauro Napoletano, GREDEG, CNRS, Université Côte d'Azur, France, and Sciences Po-OFCE, France, and SKEMA Business School, France and Institute of Economics, Scuola Superiore Sant'Anna, Pisa, Italy.

Email Address: mauro.napoletano@univ-cotedazur.fr

Andrea Roventini, Institute of Economics and EMbeDS, Scuola Superiore Sant'Anna, Pisa, Italy, and Sciences PoOFCE, France.

Email Address: andrea.roventini@santanapisa.it

Jean-Luc Gaffard, GREDEG, CNRS, Universit'e C`ote d'Azur, France, and Sciences Po-OFCE, France, and SKEMA Business School, France.

Email Address: jeanluc.gaffard@sciencespo.fr

\section{ABSTRACT}

We build an agent-based model to study how coordination failures, credit constraints and unequal access to investment opportunities affect inequality and aggregate income dynamics. The economy is populated by households who can invest in alternative projects associated with different productivity growth rates. Access to investment projects also depends on credit availability. The income of each house- hold is determined by the output of the project but also by aggregate demand conditions. We show that aggregate dynamics is affected by income distribution. Moreover, we show that the model features a trickle-up growth dynamics. Redistribution towards poorer households raises aggregate demand and is beneficial for the income growth of all agents in the economy. Extensive numerical simulations show that our model is able to reproduce several stylized facts concerning income inequality and social mobility. Finally, we test the impact of redistributive fiscal policies, showing that fiscal policies facilitating access to investment opportunities by poor households have the largest impact in terms of raising long-run aggregate income and decreasing income inequality. Moreover, policy timing is important: fiscal policies that are implemented too late may have no significant effects on inequality.

KEYWORDS

Income inequality, social mobility, credit constraints, coordination failures, effective demand, trickle-up growth, fiscal policy.

JEL

C63, D31, E63, E21. 



\title{
An agent-based model of trickle-up growth and income
}

$$
\text { inequality }
$$

\author{
Elisa Palagi* $\quad$ Mauro Napoletano ${ }^{\dagger} \quad$ Andrea Roventini ${ }^{\ddagger}$ \\ Jean-Luc Gaffard ${ }^{\S}$
}

June 23, 2021

\begin{abstract}
We build an agent-based model to study how coordination failures, credit constraints and unequal access to investment opportunities affect inequality and aggregate income dynamics. The economy is populated by households who can invest in alternative projects associated with different productivity growth rates. Access to investment projects also depends on credit availability. The income of each household is determined by the output of the project but also by aggregate demand conditions. We show that aggregate dynamics is affected by income distribution. Moreover, we show that the model features a trickle-up growth dynamics. Redistribution towards poorer households raises aggregate demand and is beneficial for the income growth of all agents in the economy. Extensive numerical simulations show that our model is able to reproduce several stylized facts concerning income inequality and social mobility. Finally, we test the impact of redistributive fiscal policies, showing that fiscal policies facilitating access to investment opportunities by poor households have the largest impact in terms of raising long-run aggregate income and decreasing income inequality. Moreover, policy timing is important: fiscal policies that are implemented too late may have no significant effects on inequality.
\end{abstract}

Keywords: income inequality, social mobility, credit constraints, coordination failures, effective demand, trickle-up growth, fiscal policy.

JEL classification: C63, D31, E63, E21

\footnotetext{
${ }^{*}$ Institute of Economics and EMbeDS, Scuola Superiore Sant'Anna, Pisa, Italy; E-mail address: elisa.palagi@santannapisa.it

†GREDEG, CNRS, Université Côte d'Azur, France, and Sciences Po, OFCE, France, and SKEMA Business School, France and Institute of Economics, Scuola Superiore Sant'Anna, Pisa, Italy; E-mail address: mauro.napoletano@univ-cotedazur.fr

${ }_{\ddagger}^{\ddagger}$ Institute of Economics and EMbeDS, Scuola Superiore Sant’Anna, Pisa, Italy, and Sciences Po, OFCE, France; E-mail address: andrea.roventini@santanapisa.it

${ }^{\S}$ GREDEG, CNRS, Université Côte d'Azur, France, and Sciences Po, OFCE, France, and SKEMA Business School, France; E-mail address: jeanluc.gaffard@sciencespo.fr
} 


\section{Introduction}

In this work we develop a model to study the interactions among inequality, credit constraints and consumption and their impact on the evolution of income distribution, social mobility and output dynamics.

Inequality is nowadays one of major concerns for society and it is increasingly studied in economics. Several studies find that inequality may hurt growth or the duration of growth spells (Ostry et al., 2011, Halter et al., 2014, Ostry et al., 2014, Cingano, 2014, Berg et al., 2018). There is also evidence that inequality is a factor influencing the emergence of crises, as the works by Fitoussi et al. (2011), Stiglitz (2012), Morelli and Atkinson (2015), Perugini et al. (2015) and Rajan (2018) suggests. Finally, inequality prevents a vast part of the population to appropriate the gains from economic growth (Lakner and Milanovic, 2013, Milanovic, 2016, Piketty et al., 2017), and it hampers social mobility (Corak, 2013, Brunori et al., 2013, Chetty et al., 2014, Güell et al., 2018).

One of the key mechanisms through which inequality can negatively affect aggregate dynamics is aggregate consumption. Empirical works show that households' propensity to save is an increasing function of households' income (Dynan et al., 2004, Bozio et al., 2011, Murugasu et al., 2013, Jappelli and Pistaferri, 2014, Carvalho and Rezai, 2015, Bunn et al., 2018, Späth and Schmid, 2018). Accordingly, higher income inequality can decrease aggregate consumption and aggregate demand, as found by Pressman (1997) and Brown (2004) in the United States in the periods 1978-2000 and 1967-1983 respectively. Such an effect can be mitigated by increasing household indebtedness, as it has happened in several countries in the last decades (see e.g. Mian et al., 2020). At the same time, increasing levels of debt can trigger major crises as the Great Recession. ${ }^{1}$

We link these different streams of literature by developing a minimalist agent-based model $^{2}$ (Gaffard et al., 2012, Dosi and Roventini, 2017, Dawid and Gatti, 2018, Dosi and

\footnotetext{
${ }^{1}$ Furthermore, Krueger et al. (2016) show that poorer households cut expenditure rates more than rich ones after a recession, providing further evidence for higher marginal propensities to consume at the bottom of the income and wealth distribution, and for the vulnerability of an economy characterized by high inequality.

${ }^{2}$ The mechanisms generating inequality and the interrelations between the distribution of income and macroeconomic performance have indeed also been investigated in a number of agent-based models (Ciarli et al., 2012, Dosi et al., 2013, Russo et al., 2016, Dosi et al., 2017b,a, Palagi et al., 2017, Russo, 2017,
} 
Roventini, 2019), where households can have asymmetric access to investment opportunities and credit and whose income dynamics can also be affected by demand externalities (Blanchard and Kiyotaki, 1987). Our model is populated by heterogeneous dynasties of households/entrepreneurs which employ labor in a project whose output is affected by idiosyncratic labor-using productivity shocks. Projects differ in the expected value of idiosyncratic shocks, and access to projects with higher expected productivity growth is subject to a fixed investment cost, which mimic e.g. education or an insurance. The product of a project is an intermediate good that is traded with "retailers" (see Bernanke et al., 1999), which in turn produce a consumption good. Retailers' expected demand fixes the production of the final good and the price they pay for the intermediate input. The latter determines - together with the output of the project - households' income.

Households in our model face binding financial constraints in investment, that impede access to more productive investment projects, as well as in consumption (in line with Banerjee and Newman, 1993, Galor and Zeira, 1993, Aghion and Bolton, 1997, Piketty, 1997, Aghion et al., 1999). In this context, higher inequality implies - coeteris paribus that the potential aggregate growth rate of the economy is lower. In addition, we introduce the possibility that inequality affects aggregate income through effective demand (Keynes, 1936, Clower and Leijonhufvud, 1975). In particular, higher inequality may result in a higher fraction of households who consume less either because of low income expectations or because of binding financial constraints. This may map in a lower level of expected consumption demand and in lower income levels for all households in the economy. The introduction of the above effective demand channel constitutes a novelty with respect to previous theoretical works on inequality and growth, as it implies that inequality may not only impact on the income potential of an economy, but also on the coordination between demand and supply. In that respect, our work is linked to the seminal works highlighting the role played by income distribution in ensuring "natural growth" (see Kaldor, 1955,

Cardaci, 2018, Caiani et al., 2019, Cardaci and Saraceno, 2019, Botta et al., 2019). In these works higher levels of either personal or functional income inequality generally worsen macroeconomic conditions. Some of the channels considered in those models include the presence of demand-led growth regimes, flexible and productivity-deteriorating labor markets and the presence of financial markets that in the long run reveal being unsustainable for households and the economy. In these studies progressive taxation schemes are generally found as being the best policy response to increasing inequality. 
Pasinetti, 1962), i.e. growth where all production factors are fully employed. However, differently from those works (and in line with modern growth analyses), the natural growth rate is not exogenous in our model, being in particular affected by income inequality as well. Moreover, demand does not stem from pre-defined "classes" of agents. Agents' heterogeneity is endogenous in our model and it is determined by access to investment opportunities (which depends also on financial conditions), as well as by the aggregate state of the economy.

We first characterize analytically the conditions for natural growth in the model. We first show that average propensity to consume is decreasing with income, and that natural growth requires that poorer households, who have a high average propensity to consume, can command a higher share of total income. Second, we derive the laws of motion for household income dynamics. We find that our model predicts that a household's income dynamics follows a Gibrat process (Gibrat, 1931), characterized by rising dispersion in incomes over time. ${ }^{3}$ However, households' income growth rate depends on the state of the economy, and when the aggregate demand is below potential output, it can be represented as a replicator dynamics with a homogeneous forcing term represented by the growth rate of aggregate demand. This result ( together with the positive impact of low-income households' consumption on aggregate demand growth) implies that our model displays a trickle-up growth mechanics. Redistributing income towards the poorest does not only raise aggregate growth. It is also beneficial for the income growth of all households in the economy independently of their initial income levels.

Finally, we carry out extensive numerical simulations in order to test the ability of the model to reproduce the main stylized facts about income inequality and social mobility, and to investigate the impact of a broad array of redistributive fiscal policies. We find that the model is able to jointly reproduce the main stylized facts about inequality, e.g.

\footnotetext{
${ }^{3}$ A recent stream of research (see e.g. Stiglitz, 2015, Gabaix et al., 2016) has also employed simple stochastic models to explain the speed at which inequality arises. These stochastic theories of earnings distribution build on the seminal contributions of Gibrat (1931) and Champernowne (1953) and focus on how different types of shocks and production technologies may have different consequences for the evolution of inequality over time. In particular, Gabaix et al. (2016), modifies the standard Gibrat's model to include (i) the presence of some high-growth types and (ii) scale dependence of the growth rate distribution with shocks that disproportionately affect high income agents.
} 
realistic levels of concentration, income growth patterns resembling the upper part of the Elephant curve (Milanovic, 2016) and the Great Gatsby curve (Corak, 2013). In addition, in presence of progressive taxation, we find that a redistributive fiscal policy providing an investment subsidy (for e.g. education) is the most effective in raising aggregate growth and in curbing market-generated inequality, whereas an income-subsidy policy achieves the strongest decrease in disposable income inequality. We also show that the timing of implementation of those policies is essential: too late interventions are not able to achieve significant reductions in inequality.

The remainder of the paper is organized as follows. In Section 2 we present our model in details. Section 3 studies analytically some key micro and macro properties of the model. Section 4 presents the results of numerical simulations. Finally, Section 5 concludes.

\section{The model}

We consider a closed economy with a constant population $N$ of heterogeneous dynasties of risk-neutral households/entrepreneurs in a discrete time horizon wherein every time step corresponds to a generation. There are homogeneous intermediate and consumption goods. At each time step, households inherit a wealth endowment from the previous generation and produce a homogeneous intermediate good. Production depends on laborusing technological progress, which is a random variable depending on a costly investment by the household. The intermediate good is then purchased by "retailers" (Bernanke et al., 1999) who convert it into a final good available for consumption. The price paid by a retailer for the intermediate input depends on its expected demand for the final good. Households set their desired consumption level on the basis of a simple behavioural rule that features income expectations, as well as social interaction effects. Investment and consumption levels can be constrained by the availability of external bank credit and thus be lower than desired ones. In what follows, we accurately describe each component of the model. 


\subsection{Production and technological progress}

Each household inherits a stock of wealth $W_{i t}$ and employs its labor $L_{i t}$ to produce a nonstorable homogeneous intermediate good employing a constant return to scale technology:

$$
Q_{i t}=A_{i t} L_{i t},
$$

where $A_{i t} \geq 1$ is the average productivity of labor. Without loss of generality we assume that $L_{i t}=1 \forall i, t$. Moreover, we assume the presence of Harrod-neutral labor-augmenting technological progress. Thus, labor efficiency in producing the intermediate good evolves according to:

$$
A_{i t}=A_{i t-1}\left(1+\gamma_{i t}\right)
$$

The rate of technological progress $\gamma_{i t}$ is a household-idiosyncratic random variable drawn from a Normal distribution $\gamma_{i t} \sim N\left(\mu_{i t}, \sigma\right)$, with $\mu_{i t}, \sigma>0$. The mean of such a distribution is affected by a costly investment undertaken by the household. More precisely, the expected value of the technical change random shock $\gamma_{i t}$ is $\mu_{2}$ if the household pays a fixed cost $I$, and it is equal to $\mu_{1}$ otherwise. Naturally, $\mu_{2}>\mu_{1}$. The assumption that the expected productivity of a project depends on a fixed cost is in line with previous works on inequality and growth with financial market imperfections (see e.g. Galor and Zeira, 1993, Banerjee and Newman, 1993, Aghion and Bolton, 1997). Typically, the fixed cost can be interpreted as e.g. investment in education or as an insurance against adverse shocks which may affect the output of the project.

At each period $t$, the output produced by households cannot be consumed but it must be traded. This introduces the motivation for market exchange and the possible emergence of coordination problems, as demand for consumption can be different from the level of potential output in the economy (see Clower and Leijonhufvud, 1975, Diamond, 1982, Howitt and Clower, 2000, for models embodying a similar idea). More specifically, entrepreneurs sell their output to retailers at a relative price $p_{Q}$. Retailers then transform the intermediate good into a homogeneous perishable final good $Y_{t}$ employing a constant 
returns to scale technology. ${ }^{4}$ Such a good also represents the numéraire in the economy and it is sold to household for consumption at a price $p_{C}$, equal to 1 for simplicity. .

\subsection{Consumption decisions}

Households consume and leave a bequest to their heirs (as in Galor and Zeira, 1993, Aghion and Bolton, 1997, Piketty, 1997). Desired consumption expenditure, $Z_{i t}$, of each generation of households depends on both expected income and consumption patterns in the reference group $\left(\bar{C}_{i t-1}^{\text {group }}\right)$, and it is set according to the following habit formation rule:

$$
Z_{i t}=\epsilon\left(\delta \bar{C}_{i t-1}^{\text {group }}+(1-\delta) Y_{i t}^{E}\right)+k_{i t}
$$

where $Y_{i t}^{E}$ is the household's expected income; $\delta, \epsilon \in(0,1) ; k_{i t}$ is a random variable drawn from a Normal distribution $k_{i t} \sim N\left(\mu_{k}, \sigma k\right)$. We assume adaptive income expectations, so that expected income is equal to the past one $Y_{i t}^{E}=Y_{i t-1}$. Moreover, $\epsilon(1-\delta)$ is the average propensity to consume out of expected income (in line with Keynes, 1936), with $\delta$ capturing the weight of the income component in the consumption decision rule. The term $k_{i t}$ is an idiosyncratic stochastic shock capturing random heterogeneity in consumption behavior, which is neither related to other households' actions, nor to expected income.

Finally, households' consumption choices are also shaped by the social environment in which they live, via the mean consumption of a household-specific group of reference $\bar{C}_{i t-1}^{\text {group }}$. The term $\epsilon \in(0,1)$ is the average propensity to consume out of the weighted average between the household's income and the average consumption in the reference group. The influence of social effects in consumption is in line with a burgeoning literature viewing consumption as shaped collectively by individuals belonging to a specific socioeconomic environment. This goes under the label of conspicuous consumption as theorised by Veblen (1899), according to whom consumers are also status seekers and emulators of consumption behaviors of individuals situated at higher points in the hierarchy. Such a social view of consumption is also embedded in theories on relative income and

\footnotetext{
${ }^{4}$ Like in (Bernanke et al., 1999) a retailer slightly modifies the good it purchases (for instance, paint the product of a different color, or add a brand). These modifications are done at no resource cost and the modified goods are the consumption goods.
} 
"keeping up with the Joneses" behavior (Duesenberry et al., 1949) theorizing that what counts is one's economic situation with respect to others'. Empirical evidence has also found support for the centrality of the social dimension in consumption, see e.g. Guven and Sørensen (2012) and Bertrand and Morse (2016). ${ }^{5}$

\subsection{Credit and household wealth}

Planned total expenditures of household $i, T E_{i t}$ include the consumption expenditure $Z_{i t}$ and the fixed investment cost $I$ :

$$
T E_{i t}=Z_{i t}+\phi_{i t} I
$$

where $\phi_{i t}$ is a variable taking value 1 if the household decides to pay the fixed cost $I$ and 0 otherwise. In appendix A.1, we show that, under quite general conditions on the expected value of the labor-efficiency shocks, risk-neutral households always have the incentive to undertake the fixed investment, so that $\phi_{i t}=1 \quad \forall i, t$.

Households finance their planned expenditures with the wealth $W_{i t}$ inherited from the previous generation, and, if it is not sufficient, with credit. More precisely, in the model agents are divided between savers and borrowers. If $Z_{i t}+I \leq W_{i t}$ then the household is a saver, who is able to pay the fixed cost, to attain a consumption level equal to the desired one, and to deposits the possible savings in a bank which pays a return $r^{s}$ on deposits. In contrast, households for whom $Z_{i t}+I>W_{i t}$ are borrowers who must rely on the credit provided by the bank to finance their planned expenditure. The credit demand, $C D_{i t}$, of a borrower is equal to:

$$
C D_{i t}=Z_{i t}+I-W_{i t}
$$

The bank provides credit up to a limit that depends on the borrower's initial wealth ${ }^{6}$

\footnotetext{
${ }^{5}$ For previous agent-based models including this social dimension of consumption see Aversi et al. (1999), Axtell (2006), Guerini et al. (2018), Cardaci and Saraceno (2019), Botta et al. (2019) and Rengs and Scholz-Wäckerle (2019).

${ }^{6}$ This is in line with models with credit rationing based on either non-observability of labor input, i.e. moral hazard (Aghion and Bolton, 1997, Piketty, 1997, Aghion et al., 1999), physical output (Banerjee and Newman, 1993, Galor and Zeira, 1993), or individual ability (Jaffee and Stiglitz, 1990).
} 
$W_{i t}$ :

$$
l_{i t}^{\max }=\rho W_{i t}
$$

where $l_{i t}^{\max }$ is the maximum credit available for the entrepreneur $i$, and $\rho>0$ is the loanto-value ratio. Clearly if $Z_{i t}+I-W_{i t}>l_{i t}^{\max }$ the above credit constraint is binding and the borrower is unable to fully realize her desired investment and consumption plans. ${ }^{7}$

At the end of each period, loans are paid back and savings are fully remunerated. The bank sets the interest rate on loans, $r^{b}$, by applying a mark-up $\mu^{b}$ on the baseline interest rate $r$ fixed by the central bank $\left(0<\mu^{b}<1\right)$. Likewise, the interest rate paid on savings, $r^{s}$, is determined by applying a mark-down $\mu^{s}$ on the baseline interest rate $\left(0<\mu^{s}<1\right)$. The terms $r, \mu^{b}$ and $\mu^{s}$ are constant. Therefore, interest rates on loans and deposits are respectively equal to:

$$
\begin{aligned}
& r^{b}=r\left(1+\mu^{b}\right) \\
& r^{s}=r\left(1-\mu^{s}\right) .
\end{aligned}
$$

Bank profits are distributed to a homogeneous class of agents (the "bankers") who entirely consume their income. Bank profits also represent a buffer against bad loans in the model and they are distributed for consumption only when the bank's net worth is high enough. Appendix A.2 presents further details about the mechanics of bank's balance sheet and the determination of total credit supply.

We can now determine the end-of-period wealth of a household $i$. If the household is a saver, it is equal to

$$
W_{i t+1}=Y_{i t}+\left(W_{i t}-Z_{i t}-I\right)\left(1+r^{s}\right)
$$

where $Y_{i t}$ is the income at the end of the period (see Section 2.4 below). If the household is a borrower and it is not credit constrained, en-of-period wealth corresponds to:

$$
W_{i t+1}=Y_{i t}+\left(W_{i t}-Z_{i t}-I\right)\left(1+r^{b}\right) .
$$

\footnotetext{
${ }^{7}$ We assume that in such a case borrowers first satisfy their basic consumption needs, postponing their investment.
} 
Finally, the end-of-period wealth of a credit-constrained household is equal to:

$$
W_{i t+1}=Y_{i t}+W_{i t}(1-\rho)\left(1+r^{b}\right) .
$$

Households who have a positive end-of-period wealth leave it as a bequest to their heirs. Such a level of wealth then constitutes the initial wealth endowment of the next generation in a dynasty.

At the opposite, households with negative end-of-period wealth go bankrupt. In this case, the next generation has no wealth. ${ }^{8}$

Figure 1 outlines the timing of activities performed by each generation in the model.

A TYPICAL TIME STEP FOR A HOUSEHOLD

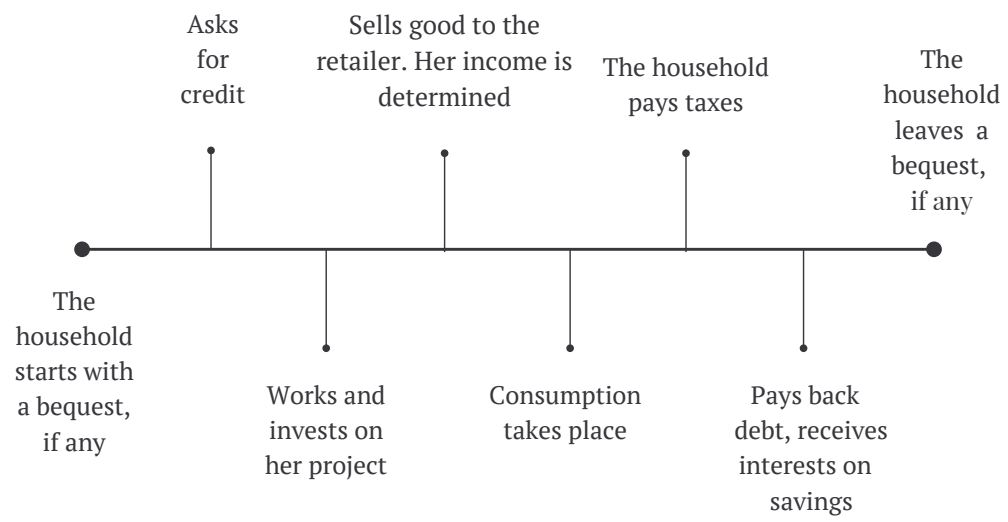

Figure 1: Timing of decisions of a household within a generation.

\subsection{The determination of aggregate and household incomes}

Households' investment and consumption levels are fully determined once the bank's credit is allotted. Aggregate demand for the final good in the economy is defined as the sum of

\footnotetext{
${ }^{8}$ If there is debt, it negatively affects the bank's balance sheet. See also appendix A.2 for more details.
} 
households' consumption and of consumption of the bankers:

$$
A D_{t}=\sum_{i=1}^{N} C_{i t}+\pi_{t}^{b}
$$

where $C_{i t}$ is the level of household's $i$ consumption and $\pi_{t}^{b}$ are distributed bank profits. ${ }^{9}$ Notice that the household's actual consumption $C_{i t}$ can be lower than desired consumption $Z_{i t}$ depending on whether the household is credit-constrained or not.

In line with the principle of effective demand (Keynes, 1936), we assume that retailers set the level of output to produce, $Y_{t}$, on the basis of expected aggregate demand. Aggregate demand can be lower than the notional supply of intermediate output $Q_{t}=\sum_{i} Q_{i t}$. In this typical Keynesian scenario, aggregate output will be equal to aggregate demand $A D_{t}$ and the excess production of intermediate goods is lost. At the other extreme, aggregate demand can be equal or higher than the notional supply of the intermediate output $Q_{t}$. In this scenario, aggregate output will be constrained by the supply of intermediate output produced by households, which sets also the potential output for the economy. More formally, aggregate output is determined according to the following equation:

$$
Y_{t}=\min \left\{A D_{t}, Q_{t}\right\}
$$

Gaps between aggregate demand and potential output map into different relative prices of the intermediate output $p_{Q}$, which in turn affect households' income. We assume that retailers operate in a perfectly competitive environment at zero profits. These assumptions, combined with the hypothesis of constant returns to scale in final good production, implies that aggregate output is fully distributed among the factors that have contributed to their production, i.e.:

$$
Y_{t}=\sum_{i=1}^{N} p_{Q} Q_{i t}=p_{Q} Q_{t} \sum_{i=1}^{N} \frac{Q_{i t}}{Q_{t}} .
$$

As $\sum_{i=1}^{N} \frac{Q_{i t}}{Q_{t}}=1$, we obtain that the relative price of the intermediate input $p_{Q}$ is simply

\footnotetext{
${ }^{9}$ In fact, bankers are like rentiers in our model. They do not contribute directly to the production of the final output and they extract their income, through interests, from households. For this reason, bankers' consumption also corresponds to an autonomous injection in the circular flow that determines aggregate income in our economy. More on that in Section 3.1 below.
} 
equal to: ${ }^{10}$

$$
p_{Q}=\frac{Y_{t}}{Q_{t}}
$$

Thus, a level of aggregate demand below potential output $\left(A D_{t}<Q_{t}\right)$ will result into a lower relative price paid by retailers to households to purchase their production of the intermediate input. Household income is thus equal to $p_{Q} Q_{i t}$. Combining Eq. 15 with 13, one gets that household income will be equal to:

$$
Y_{i t}=\frac{Q_{i t}}{Q_{t}} A D_{t}
$$

whenever the aggregate demand constraint is binding, i.e. when $A D_{t}<Q_{t}$. A household's income is instead equal to $Q_{i t}$ when notional supply is fully purchased, i.e. when $A D_{t} \geq$ $Q_{t}$

\section{Analytical micro and macro properties of the model}

We begin our study of the model developed in the previous sections by investigating analytically some of its properties at the micro and macro levels. We first show, in Section 3.1 how income distribution introduces constraints on aggregate output growth both from supply and demand side. In particular, we show the key role of households' average propensity to consume in ensuring that the economy follows a growth trajectory where all resources are fully employed. Next, in Section 3.2, we focus on the microdynamics of individual incomes, and we show how household income growth depends on the state of the economy.

\subsection{Income distribution and aggregate dynamics}

The maximum amount of output that can be produced in the model is determined by the supply of intermediate output, which in turn is affected by the investments undertaken

\footnotetext{
${ }^{10}$ Alternatively, we could assume that retailers have some market power. This would just complicate the algebra without affecting the results. Indeed, in the case where retailers operate in imperfect competition Equation (14) becomes $(1-\mu) Y=\sum_{i=1}^{N} p_{Q} Q_{i t}$ where $\mu$ is the retailers' mark-up rate (which also corresponds to their profit share). In such a case the price of intermediate input is equal to $p_{Q}=\frac{Y_{t}}{Q_{t}}(1-\mu)$.
} 
by households, mimicking e.g. the role of education. Some agents have to borrow to pay the fixed cost necessary to obtain higher expected returns. Borrowers who are credit constrained will be unable to pay the fixed cost $I$, and will thus experience a lower expected increase in production. It follows that, in this case, the potential growth rate of the economy will be lower.

More formally, denote by $N_{t}^{H E} / N\left(N_{t}^{L E} / N\right)$ the share of agents who are (not) able to pay the fixed cost in period $t$ and thus have access to the distribution of productivity shocks with the higher (lower) mean $\mu_{2}\left(\mu_{1}\right)$. The growth rate of potential output in expected terms, $E\left(g_{t}^{N}\right)$, is then equal to:

$$
E\left(g_{t}^{N}\right)=\frac{N_{t}^{H E}}{N} \mu_{2}+\frac{N_{t}^{L E}}{N} \mu_{1}
$$

Given that $\frac{N_{t}^{H E}}{N}=1-\frac{N_{t}^{L E}}{N}$ we can write the last equation as

$$
E\left(g_{t}^{N}\right)=\mu_{2}+\frac{N_{t}^{L E}}{N}\left(\mu_{1}-\mu_{2}\right)
$$

As $\mu_{1}<\mu_{2}$, it follows that the potential growth rate of the economy will be lower when the share of agents not able to pay the fixed investment $I$ is higher. The growth rate of potential output in our model (with fixed population and labor-using technical change) corresponds to the natural growth rate in the seminal works of Harrod (1939), Domar (1946) and Solow (1956). However, differently from those works, the natural growth rate is endogenous in our model, as it depends on the share of agents in the population undertaking the fixed investment $I$, and it is thus affected by the financial constraints discussed in Section 2.3. Moreover, aggregate growth can be lower than the natural one due to the constraints stemming from the demand side of the economy, i.e., when $A D_{t}<Q_{t}$. In this case, the growth rate of the economy corresponds to that of aggregate consumption.

The demand constraint can be linked to income distribution. Indeed, if one assumes that all households in the economy are able to satisfy their desired consumption plans, 
the condition for natural growth can be written as:

$$
\sum_{i=1}^{N} Z_{i t}+\pi_{t}^{b} \geq Q_{t}
$$

where $Z_{i t}$ is household desired consumption determined by Equation (3). By dividing both sides of the above inequality by $Q_{t}$ and then by multiplying and dividing all terms in the summation by household's potential income $Q_{i t}$ we get:

$$
\sum_{i=1}^{N} \theta_{i t} \frac{Q_{i t}}{Q_{t}}+\frac{\pi_{t}^{b}}{Q_{t}} \geq 1
$$

where $\theta_{i t}$ is household's $i$ desired average propensity to consume out of potential income $\theta_{i t}=Z_{i t} / Q_{i t}$ and $\frac{\pi_{t}^{b}}{Q_{t}}$ is the average propensity to consume of bankers. In line with Kaldor (1955), the inequality in (20) states that natural growth requires that households with the relatively higher average propensity to consume also hold a corresponding higher share of potential income.

The consequences of the condition in (19) are well captured by the special case where households are split into two homogeneous groups, respectively high-propensity $(h p)$ and low-propensity $(l p)$ consumers. Denote respectively by $\theta^{h p}$ and by $\theta^{l p}$ the average propensity to consume out of potential income of these two groups (with $\theta^{h p}>\theta^{l p}$ ) and by $\beta^{h p}$ and $\beta^{l p}$ their respective income shares. Note that as only households contribute to output production in the model, the latter income shares are such that $\beta^{l p}=1-\beta^{h p}$. The condition (20) for natural growth in this simple two-groups case boils down to:

$$
\left(\theta_{t}^{h p}-\theta_{t}^{l p}\right) \beta_{t}^{h p}+\theta_{t}^{l p}+\frac{\pi_{t}^{b}}{Q_{t}} \geq 1
$$

As the expression on the left hand side is an increasing function of the income share of high-propensity consumers as long as $\theta_{t}^{h p}>\theta_{t}^{l p}$, natural growth requires that $\beta_{t}^{h p}$ satisfies:

$$
\beta_{t}^{h p} \geq \frac{1-\theta_{t}^{l p}-\frac{\pi_{t}^{b}}{Q_{t}}}{\theta_{t}^{h p}-\theta_{t}^{l p}}
$$


Given that households' income shares cannot be higher than 1, the right hand side of the latter inequality must be lower than 1 , thus requiring that:

$$
\theta_{t}^{h p}>1-\frac{\pi_{t}^{b}}{Q_{t}}
$$

Taken together, the last two inequalities help to better understand the conditions for natural growth in our model. Condition (22) states that natural growth requires that households with a high average propensity to consume also receive a high share of potential income. As shown in Section 2.1, these shares depend on the efficiency of households in producing the intermediate input, which in turn is determined by their ability to pay the fixed investment required to get the higher expected productivity gains. It follows that credit constraints that impair some households to access better investment opportunities not only result into a lower natural growth rate, but they also prevent the economy to generate enough aggregate demand to absorb the supply of intermediate input. As a consequence, the aggregate output growth rate will systematically be below the natural one.

Furthermore, the inequality in (23) shows that in order to achieve natural growth, a high share of the income received by high-propensity households needs to be devoted to consumption. We can study how average propensity changes as a function of potential income by using the behavioral rule for desired consumption in Eq. (3). The expected household desired average propensity to consume is equal to:

$$
E\left(\theta_{i t}\right)=\epsilon \delta \frac{\bar{C}_{i t-1}^{\text {group }}}{Q_{i t}}+\epsilon(1-\delta) \frac{Y_{i t}^{E}}{Q_{i t}}
$$

In the special case where households expect their income to be equal to potential one (i.e. $\left.Y_{i t}^{E}=Q_{i t}\right)$, the above expression boils down to:

$$
E\left(\theta_{i t}\right)=\epsilon \delta \frac{\bar{C}_{i t-1}^{\text {group }}}{Q_{i t}}+(1-\delta) .
$$

Thus, for given levels of socially desired consumption $\bar{C}_{i t-1}^{\text {group }}$ and expected income $Y_{i t}^{E}$, 
households with a lower (higher) level of potential income will have a higher (lower) average propensity to consume. It follows that, in line with traditional Keynesian analyses, redistributing income towards poorer households has the effect of increasing aggregate demand and - when condition (19) is also fulfilled - it allows to attain natural growth. Equation (24) also highlights a final effect of credit constraints in the model. Indeed, credit constraints binding consumption expenditures of poor households also decrease the average propensity to consume of these households and thus aggregate demand.

The above conclusions are conditional on given levels of socially desired consumption $\bar{C}_{i t-1}^{\text {group }}$ and expected income $Y_{i t}^{E}$. A decrease in one of these two variables will result in a fall of households' average propensity to consume. In other words, the expression in (24) also indicates that the average propensity to consume of poor households groups can be low if they expect their incomes to be much lower than the potential or if they imitate reference groups with low consumption standards. In particular, as households form income expectations on the basis of observed past income levels (see Section 2.2), prolonged periods of below-potential output will depress income expectations, thus lowering the average propensities to consume of poor households.

\subsection{The dynamics of household incomes}

After having characterized aggregate income dynamics, we can zoom at the micro level to characterize household income dynamics. Such dynamics will be different according to whether the economy is on its natural growth trajectory or not.

Let's start with the case where the economy grows at the natural rate and aggregate demand is thus equal to potential output (or higher). In this situation, household income is at the potential level, which corresponds to the household's production of the intermediate input, i.e. $P_{Q}=1$. Equations (1) and (2) together with the assumption that $L_{i t}=1 \forall i, t$ imply that the law of motion of a household's potential income (in logs) is:

$$
q_{i t}=q_{i t-1}+\gamma_{i t}
$$


with $q_{i t}=\log \left(Q_{i t}\right)$. The equation implies that the household income growth rate is equal to the labor efficiency shock $\gamma_{i t}$. In turns, household incomes evolve according to a Gibrat process (Gibrat, 1931), which implies a rising dispersion in income levels as time goes by. In this respect, our model differs from previous theories of income distribution which assume decreasing marginal productivity in factor use and imply convergence in income levels unless some frictions are at work. ${ }^{11}$

At the same time, the process driving potential income growth in our model departs in some relevant ways from the standard Gibrat one. The latter process assumes that the growth rate of income is independent from past income, whereas in the model, expected income growth rate is a function of past income, which affects the ability of a household to finance the fixed investment I (see Section 2.3). In particular, the expected growth rate of potential income $E\left(\gamma_{i t}\right)$ takes the value $\mu_{2}$ or $\mu_{1}$ according to whether a household has been able to pay the fixed cost (through credit or her own wealth) or not (due to credit rationing). It follows that credit constraints amplify the income asymmetries already embedded in the Gibrat process.

When the economy is away from the natural growth path, and thus aggregate demand is below potential output, household income is given by the expression in Equation (16), which can be written as:

$$
Y_{i t}=\frac{Q_{i t}}{N \bar{Q}_{t}} A D_{t}
$$

where aggregate potential output $Q_{t}$ is replaced with $N \bar{Q}_{t}$, where $N$ is the (fixed) population of households and $\bar{Q}_{t}$ is average household production. Considering the same equation at time $t-1$, dividing $Y_{i t}$ by $Y_{i t-1}$, and taking logs we get:

$$
y_{i t}=y_{t-1}+\left[\left(\gamma_{i t}-\bar{\gamma}_{t}\right)+g_{A D_{t}}\right]
$$

which shows that household income follows a Gibrat process also when the economy is

\footnotetext{
${ }^{11}$ For instance, Stiglitz (2015) shows how the basic Solow model generalized to heterogeneous dynastic families would imply convergence in incomes. Stiglitz (2015) then presents several extensions, such as random or variable returns to capital, in order to explain income and wealth inequality, still always keeping the assumption of decreasing returns. Differently from Piketty (1997), who needs to add credit constraints to the standard Solow model in order to generate persistent inequality (in this case the focus is on wealth), imperfect capital markets are not necessary for us.
} 
away from the natural growth path. Differently from Equation (26), the income growth rate is now a function of the growth rates of household's production $\gamma_{i t}$, average production $\bar{\gamma}_{t}$, and aggregate demand $g_{A D_{t}}$ :

$$
g_{Y_{i t}}=\left(\gamma_{i t}-\bar{\gamma}_{t}\right)+g_{A D_{t}}
$$

Equations (28) and 29 show that - away from natural growth - household income dynamics can thus be characterized by a replicator dynamics with a forcing term ${ }^{12}$ corresponding to aggregate demand growth: the income of households who are less productive than the average grows less than aggregate demand, while the opposite occurs for more productive households. The equation also shows that an increase in aggregate demand, which stems from consumption growth, will result into higher incomes for all agents. It follows that an increase in consumption by one household will generate a positive demand externality (Blanchard and Kiyotaki, 1987) on all other households in the economy. As the average propensity to consume is higher among poor households (see Equation 24), our model thus features a trickle-up income dynamics, where redistribution towards the poor is beneficial for the growth of income of all agents in the economy. ${ }^{13}$

\section{Simulation results}

After having characterized analytically the properties of aggregate and household income dynamics in the model, we now turn to a full-fledged investigation of its properties by employing Monte Carlo simulations (see Fagiolo and Roventini, 2017, Fagiolo et al., 2019, for a discussion of empirical validation and policy analysis in agent-based models).

The simulations analyses we perform have two objectives. First, we explore the ability of the model to match the main stylized facts about growth and income inequality and

\footnotetext{
${ }^{12}$ For a discussion of the replicator dynamics and its properties see Dosi et al. (2017a).

${ }^{13}$ Note that income shares are not directly affected by the fact that the economy grows at the natural rate or not. Indeed, household's income share is always be equal to its share in the production of the intermediate input $Q_{i t} / Q_{t}$, regardless of the state of the economy. However, income shares are indirectly affected by the state of the economy, as households' income growth contributes to determining the endof-period wealth of each generation, and thus the possibilities of financing the fixed investment cost of their offsprings.
} 
to study how such regularities are related to key properties of our model (cf. Section 4.1). The second objective is to understand the possible impact of different types of fiscal policies in moderating income inequality and in promoting aggregate growth (see Section 4.2). Given the importance of credit in our model, we compare simulations both in a scenarios with credit constraints (cf. Eq. 6) and in one without limit to credit.

All results refer to a sample of 50 independent Monte Carlo runs (MC henceforth). The values of the model's parameters used in the simulations are reported in Table 6 in Appendix B. As far as initial conditions are concerned, we assume a quite egalitarian economy: we draw initial potential incomes randomly in order to get an initial Gini coefficient of around 0.1. ${ }^{14}$ Further details about initial conditions can be found in Appendix B.

\subsection{Empirical validation}

Figure 2 shows the densities (pooled across 50 Monte Carlo runs) of the logarithm of household incomes for the final period $(T=5000)$ in the two scenarios with and without credit constraints. ${ }^{15}$ The comparison of the two distributions clearly indicates that the introduction of credit constraints generates a more dispersed income distribution in the long-run. In addition, the distribution is also bi-modal, which implies the existence of two clusters of households whose income in the long-run are dispersed across two different means (see Quah, 1996, for more discussion about the consequences of bi-modality in the distribution of long-run incomes). The lower mode is composed by households that are left behind due to credit constraints and unequal access to opportunities. Indeed, in presence of credit constraints, some households are unable to finance the investment cost required to get higher expected productivity growth and so they draw their shocks from a distribution with a lower mean.

\footnotetext{
${ }^{14}$ This value for the Gini coefficient represents a very low level of inequality, hardly observable in real world data, even in the most egalitarian countries.

${ }^{15}$ In line with the literature, we do not consider the transient phase in our analysis (averages will be calculated over the last 500 periods, i.e. 4500-5000). Agent-based models are typically characterised by a transient phase that precedes the long-run statistical equilibria and/or emergent properties of aggregate dynamics, that is when the behavior of the process becomes sufficiently stable (Fagiolo and Roventini, 2017).
} 


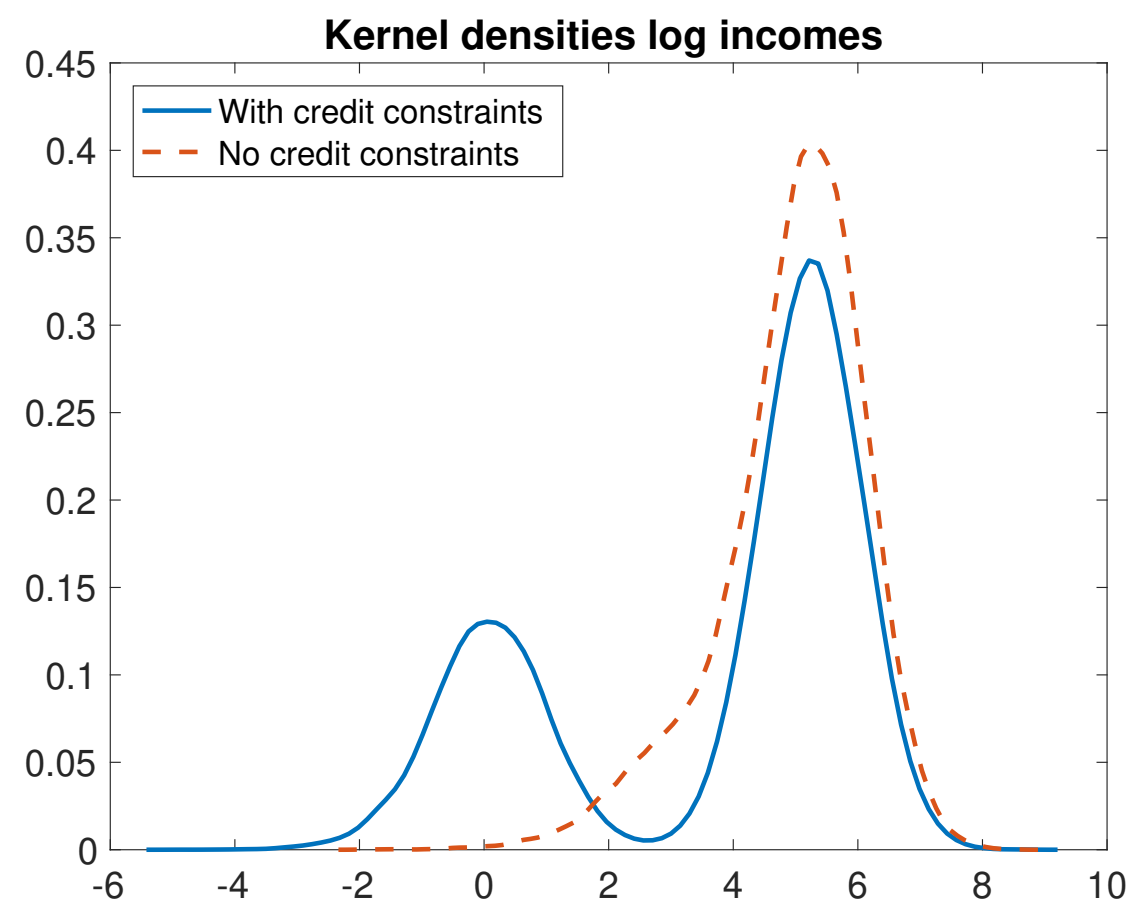

Figure 2: Kernel density estimation for log incomes in the final period for the scenario with credit constraints vs. the scenario without credit constraints, $50 \mathrm{MC}$ pooled.

The qualitative insights provided by Figure 2 are confirmed by the comparison of the average degree of inequality that emerges in the two scenarios, captured both by the mean Gini coefficient and the mean share of income accruing to the Top $10 \%$ of households. Table 1 shows that the introduction of credit constraints brings a statistically significant increase in both measures together with a small but statistically significant fall in the level of long-run aggregate income (in line with the results discussed in Section 3.1). Indeed, binding credit constraints imply a lower average propensity to consume and can thus result into an aggregate growth rate lower than the natural level. The results in Table 1 also suggest that our model generates an inverse relation between income inequality and aggregate growth. ${ }^{16}$

Further elements about the inequality dynamics emerging in our model are provided by the mean income growth of dynasties at different percentiles of the income distribution, also called growth incidence curves (cf. Figure 3). In line with the previous findings, we

\footnotetext{
${ }^{16}$ Furthermore, we also test the effects of changes in some key parameters. A lower standard deviation in the distributions of labor efficiency shocks and a lower distance between means of the distributions of shocks decrease inequality, while leaving unaltered or slightly increasing aggregate income. Moreover, a higher investment cost increases income dispersion while worsening macroeconomic conditions. Results might be provided upon request.
} 


\begin{tabular}{lllc}
\hline Scenario & Y & Gini & Top 10\% \\
\hline No credit constraints & 1 & 1 & 1 \\
With credit constraints & $0.977^{* *}$ & $1.220^{* *}$ & $1.136^{* *}$ \\
\hline
\end{tabular}

Table 1: Aggregate income and inequality indicators in scenarios without and with credit constraints. Statistics are mean values over the last 500 periods and over 50 MC repetitions. Significant difference wrt. baseline at $1 \%(* *)$ and $5 \%$ level $(*)$.

observe that the income growth at different percentiles of the income distribution is more balanced in the scenario with no credit constraints (see left panel in Figure 3), whereas growth rates are much more polarised when imperfect capital markets are present (cf. right panel in Figure 3). ${ }^{17}$ The shape of these curves is reminiscent of the upper part of the Elephant curve (Lakner and Milanovic, 2013, Milanovic, 2016), which shows that in the period 1988-2008, in rich countries, households belonging to lower percentiles in the income distribution grew at a much lower rate than those belonging to the upper ones. In addition, our results are also in line with evidence presented by Piketty et al. (2017), showing growth rates of incomes at different percentiles of the income distribution for US households.

Credit constraints do not only influence income inequality within generation, but also between generations, as they induce lower income growth both at the individual and aggregate levels. Figure 4 captures the degree of social mobility emerging in our model by showing quartile transition probabilities for households' incomes in different generations, i.e. the probabilities $p_{i j}$ of a household of ending up in state $j$ if its dynasty started in state $i$. These are based on transition probability matrices (see Table 2), commonly used in the literature (see e.g. Corak and Heisz, 1999, Mazumder, 2005). ${ }^{18}$

\footnotetext{
${ }^{17}$ In addition, the scenario with credit constraints also generates a Pareto tail in the distribution of incomes. By using the procedure presented in Clauset et al. (2009) we find that the top 0.2 percent of incomes are Pareto distributed with an estimated $\alpha$ coefficient which is equal to 5.0185. The presence of a Pareto upper tail in the distribution of incomes is in line with empirical evidence (see e.g. Clementi and Gallegati, 2005, Jenkins, 2017).

${ }^{18}$ These probabilities are computed by counting the number of observations that experienced a given transition to another (or the same) state. Norris (1998) shows that this corresponds to the maximum likelihood estimators of true probabilities. To make it clearer, entry $(1,1)$, and hence the height of bar $(1,1)$, shows the percentage of dynasties who were in the bottom $25 \%$ of the income distribution at the initial period and that find themselves in the bottom $25 \%$ of the distribution also in the last period. Entry $(1,2)$, and the height of bar $(1,2)$, shows the percentage of dynasties who were in the bottom $25 \%$
} 


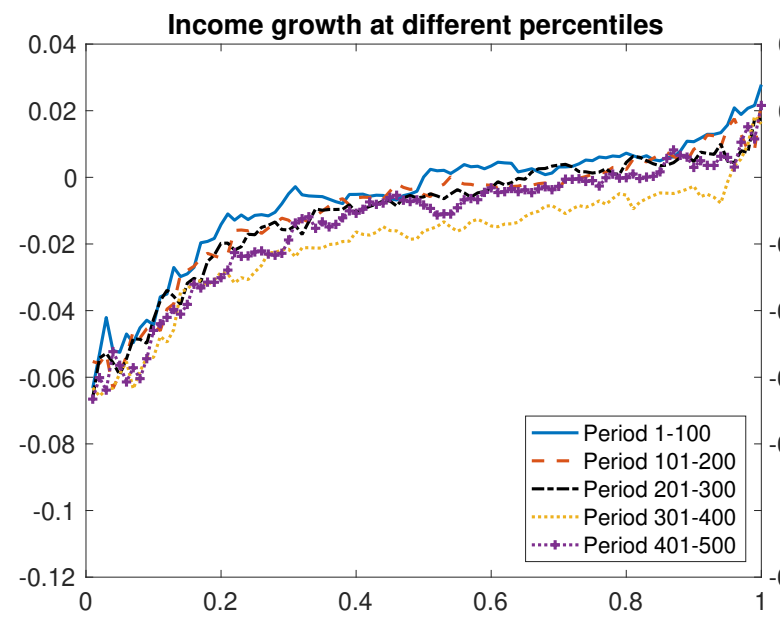

(a) No credit constraints

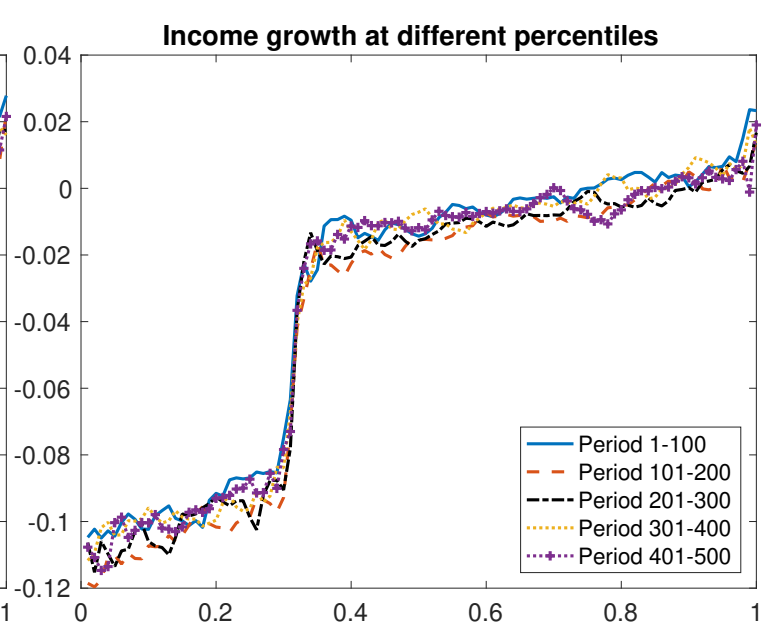

(b) With credit constraints

Figure 3: Percentile income growth (50 MC averages). Since we exclude the transient, growth over the first 100 periods in the figure is actually referring to period 4501-4600 (analogous for other subperiods).

In line with previous works (see e.g. Becker and Tomes, 1979, 1986, Caucutt and Lochner, 2020), Figure 4 and Table 2 indicates that credit constraints considerably reduce social mobility: the mean persistence — defined as the average value the matrix displays on the main diagonal - in the scenario with credit constraints is significantly higher than in the case when they are not present. Lower social mobility also results in lower aggregate output and higher income inequality, in line with the empirical evidence (Corak, 2013, Güell et al., 2018). Finally, the transition probabilities of the extreme entries in the matrix, i.e. entries and bars $(1,1)$ and $(4,4)$, are higher than those in the middle, pointing out that social mobility is higher for households in central parts of the distribution, again in line with empirical findings (Corak and Heisz, 1999, Mazumder, 2005, OECD, 2018).

In fact, the negative association between income inequality and intergenerational mobility is a well known stylized fact, the so called Great Gatsby curve (Krueger, 2012, Corak, 2013), which is a genuine emergent property generated by the model. As visible in Figure 5, scenarios with higher investment costs, which thus entail higher costs for accessing better opportunities, tend to be associated to greater social immobility, again of the income distribution at the initial period who find themselves in the 2nd quartile of the distribution in the final period. 


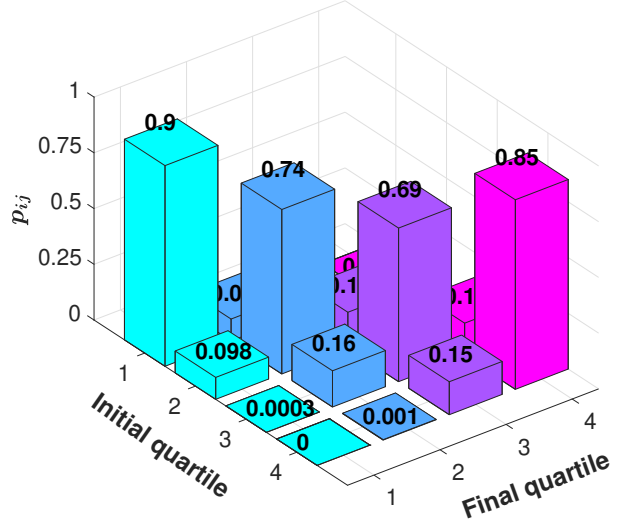

(a) No credit constraints

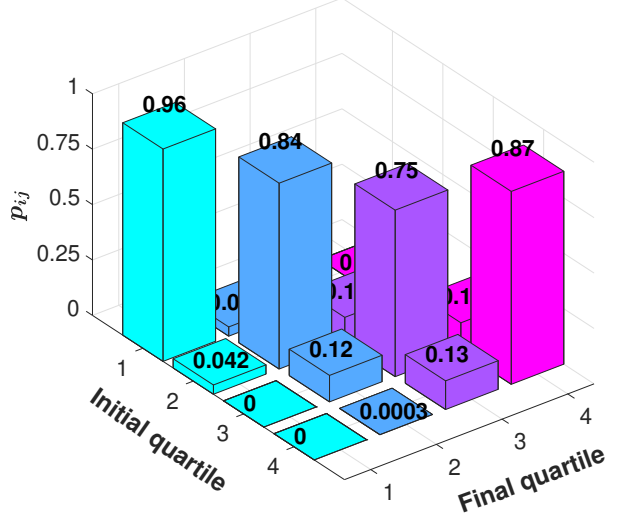

(b) With credit constraints

Figure 4: Graphical representation of income transition matrices from $t=4500$ to $t=5000$ (50 MC averages). Income distribution divided into 4 quartiles. Each bar represents the probability of a household of ending up in quartile $j$ if its dynasty started in quartile $i$.

measured by mean persistence on the diagonal of the income transition matrix, and to greater inequality levels.

Finally, the model is able to generate inequality levels that are reasonably in line with empirical evidence. For this purpose, we take the credit constraints scenario as the benchmark. Table 3 shows that Monte Carlo average values of Gini coefficients computed on households' incomes at the final time step of the simulation is 0.60 , which is exactly equal to that in the United States for the latest available observation estimated by the World Inequality Database (Alvaredo et al., 2018). Our Top 10\% income share resulting from the benchmark simulation - 39.4\% of total income - is lower than the U.S. one, one of the highest among the developed countries, but in tune with those of other OECD countries. ${ }^{19}$ Moreover, in line with empirical observations, our model delivers income shares accruing to the bottom $50 \%$ in the income distribution that are very low, but not far from US ones (see the comparison in Table 3).

\footnotetext{
${ }^{19}$ For instance, in 2014, in France and Germany top income share are respectively equal to is $33 \%$ and 34\%, while in Canada in 2010 it corresponds to 41\% (Source: WID, Alvaredo et al. 2018).
} 


\begin{tabular}{c|cccc}
\hline \hline & 1 & 2 & 3 & 4 \\
\hline 1 & 0.9016 & 0.0983 & 0.00008 & 0 \\
& $(0.0021)$ & $(0.0021)$ & $(0.0001)$ & \\
2 & 0.0981 & 0.7377 & 0.1624 & 0.0018 \\
& $(0.0021)$ & $(0.0026)$ & $(0.0023)$ & $(0.0004)$ \\
3 & 0.0003 & 0.163 & 0.6889 & 0.1478 \\
& $(0.0002)$ & $(0.0023)$ & $(0.0033)$ & $(0.0022)$ \\
4 & 0 & 0.001 & 0.1486 & 0.8503 \\
& & $(0.0003)$ & $(0.0023)$ & $(0.0022)$ \\
\hline \hline
\end{tabular}

(a) No credit constraints

\begin{tabular}{c|cccc}
\hline \hline & 1 & 2 & 3 & 4 \\
\hline 1 & 0.9583 & 0.0417 & 0 & 0 \\
& $(0.0011)$ & $(0.0011)$ & & \\
2 & 0.0417 & 0.8386 & 0.1194 & 0.0003 \\
& $(0.0011)$ & $(0.0027)$ & $(0.0024)$ & $(0.0002)$ \\
3 & 0 & 0.1194 & 0.7514 & 0.1293 \\
& & $(0.0024)$ & $(0.0029)$ & $(0.0019)$ \\
4 & 0 & 0.0003 & 0.1293 & 0.8704 \\
& & $(0.0002)$ & $(0.002)$ & $(0.002)$ \\
\hline \hline
\end{tabular}

(b) With credit constraints

Table 2: Transition matrices for scenario without credit constraints (a) and for scenario with credit constraints (b) from $\mathrm{t}=4500$ to $\mathrm{t}=5000$. MC standard errors in brackets. Income distribution divided into 4 quartiles.

\begin{tabular}{lccc}
\hline & Gini & Top 10\% & Bottom 50\% \\
\hline Model-Generated & 0.60 & $39.4 \%$ & $8.4 \%$ \\
United States & 0.60 & $47.0 \%$ & $12.6 \%$ \\
\hline
\end{tabular}

Table 3: Inequality statistics comparison between our model benchmark scenario (with credit constraints) and empirically-observed values for the USA. Source for USA data: WID. Equal-split adults pre-tax national income.

\subsection{Fiscal policy experiments}

After testing the ability of the model in reproducing empirical evidence on income inequality, we now turn to a battery of experiments on different fiscal policies in order to study their impact on income distribution, intra-generational distribution of resources and, more generally, on economic dynamics. All experiments are performed under balanced-budget rules.

We first consider a policy where the government collects taxes from households in order to finance the purchase of the final good. The aggregate demand equation (12) is modified so that:

$$
A D_{t}=\sum_{i=1}^{N} C_{i t}+\pi_{t}^{b}+G_{t} .
$$

where $G_{t}$ is government final consumption. The latter is equal to collected taxes on income 


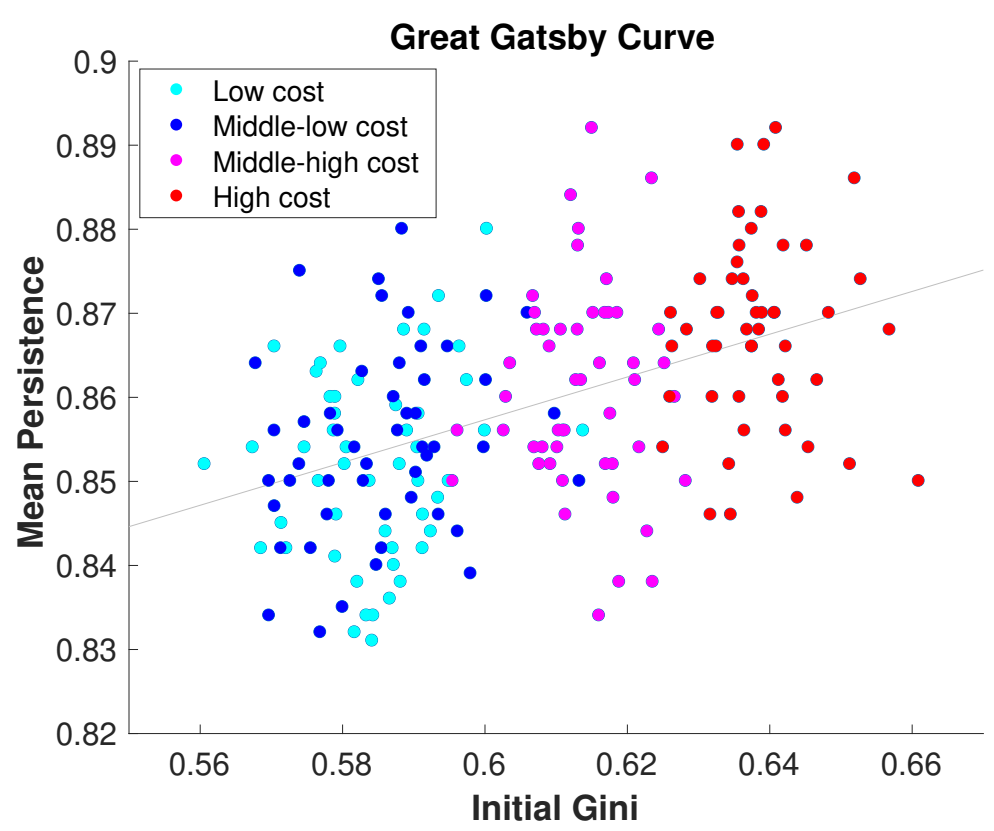

Figure 5: The Great Gatsby curve for scenarios with different levels of the investment cost. Initial Gini at the beginning of the period under analysis (4500-5000) and mean persistence on the transition probability matrix diagonal (built from $\mathrm{t}=4500$ to $\mathrm{t}=5000$ ).

$T_{t}$ :

$$
G_{t}=T_{t}=\sum_{i=1}^{N} \tau\left(Y_{i t}\right) \cdot Y_{i t}
$$

where $\tau\left(Y_{i t}\right)$ is the income tax rate. ${ }^{20}$ We consider two different types of tax policy: one with proportional tax and one with progressive taxation. With a proportional tax scheme $\tau\left(Y_{i t}\right)=\tau$ with $\tau \in[0,1] \quad \forall i, t$. In the simulation experiments, we set $\tau=10 \%$. With a progressive taxation, the tax rate increases with gross household income $\tau^{\prime}\left(Y_{i t}\right)>0$. More precisely, we simply divide the population in four income quartiles, and we set increasing tax rates, namely $1 \%, 5 \%, 10 \%$ and $15 \%$.

The first three lines of Table 4 show the impact of such fiscal policies on aggregate product, pre-tax and post-tax and transfers income inequality (proxied by Gini indexes), and compare them to the benchmark scenario without government interventions but with credit constraints. Balanced-budget government consumption has always a significant positive impact on long-run aggregate income under both taxation schemes. However, government consumption financed with a proportional tax scheme has no significant im-

\footnotetext{
${ }^{20}$ Clearly, in presence of taxation, household disposable income is $\left(1-\tau\left(Y_{i t}\right)\right) Y_{i t}=\left(1-\tau\left(Y_{i t}\right)\right) p_{Q} Q_{i t}$.
} 
pact on income inequality. In contrast, a progressive tax scheme reduces both the preand post-tax Gini indexes vis-á-vis the benchmark scenario.

The positive and significant impact on long-run income under balanced-budget conditions indicates that government consumption has a crowding-in effect on on aggregate expenditure. Indeed, by increasing aggregate demand, government consumption contributes to increase the relative price of the intermediate input and thus the incomes of all households in the economy. Under adaptive income expectations, the higher income of the current generation then maps into higher average propensities to consume of future generations (see Eq. (24) in Section 3.1).

Moreover, higher incomes also result into higher wealth levels for the next generations, thus contributing to lessen financial constraints, especially for poor households, which can now invest more in the technology (e.g., education) delivering higher productiivty shocks. At the same time, Equation (28) makes clear that - when aggregate output is below potential - the effects of an increase in aggregate demand will spread equally across the different households within a generation. It follows that most redistributive effects do not stem from the rise in aggregate demand, but from the taxation scheme. This explains why the proportional taxation scheme has a weak redistributive effect, while the opposite holds for progressive taxation (cf. Table 4).

Finally, the progressive taxation scheme significantly lowers both pre- and post-tax income inequality, in line with Roine et al. (2009), Piketty et al. (2014), Dabla-Norris et al. (2015) and Jaumotte and Osorio Buitron (2020). The reason is that such a taxation scheme collects more taxes which translates in higher levels of government consumption, thus boosting income. From an inter-generational perspective, progressive taxation allows a larger share of poor dynasties to finance the fixed investment cost and so to catch up the income levels of wealthier families. ${ }^{21}$

\footnotetext{
${ }^{21}$ Clearly, the fact that a larger share of households is able to pay the fixed cost has also a beneficial effect on the natural growth rate and it increases potential income in the long-run. This last effect is much stronger when the government expenditure is explicitly targeted to finance the investment cost of poor households as we discuss below.

${ }^{22}$ Emerging values of Gini coefficients are realistic and are ranging between 0.4400 and 0.5943 for market income, between 0.3560 and 0.5943 for net disposable income, with the upper bound being equal because related to the benchmark scenario with no redistributive policy. All values are available upon request.
} 


\begin{tabular}{llcc}
\hline Policy Scenario & Y & Pre-tax Gini & Post-tax Gini \\
\hline Benchmark scenario & 1 & 1 & 1 \\
\hline Govt. consumption with proportional tax & $1.011^{* *}$ & 0.9914 & 0.9914 \\
Govt. consumption with progressive tax & $1.025^{* *}$ & $0.9186^{* *}$ & $0.8918^{* *}$ \\
\hline Income subsidy with progressive tax & $1.031^{* *}$ & $0.8225^{* *}$ & $0.5990^{* *}$ \\
Investment subsidy with progressive tax & $1.036^{* *}$ & $0.7404^{* *}$ & $0.6999^{* *}$ \\
\hline Govt. consumption with high top progressive tax & $1.040^{* *}$ & $0.8582^{* *}$ & $0.7676^{* *}$ \\
Income subsidy with high top progressive tax & $1.036^{* *}$ & $0.7914^{* *}$ & $0.4028^{* *}$ \\
Investment subsidy with high top progressive tax & $1.050^{* *}$ & $0.7321^{* *}$ & $0.6221^{* *}$ \\
\hline
\end{tabular}

Table 4: Aggregate income and inequality indicators in different policy scenarios. Statistics are mean values over the last 500 periods and over $50 \mathrm{MC}$ repetitions. All statistics are reported in relation to benchmark scenario. Significance difference wrt. benchmark at $1 \%\left({ }^{*}\right)$ and $5 \%$ level $(*)$. In the last six scenarios post-tax (and transfers) Gini is also significantly different from pre-tax Gini. ${ }^{22}$

Let us now consider two other types of fiscal policy experiments. More precisely, in the third policy scenario, we keep the progressive taxation scheme, but we assume that the collected resources are used to finance a lump-sum income subsidy $s\left(Y_{i t}\right)$ for the poorer households, i.e. those below the median. The subsidy $s\left(Y_{i t}\right)$ is equal to $T_{t} / n_{q}$ and it is distributed to households whose market income is lower or equal to the 50 th percentile of the income distribution, with $n_{q}$ being the number of households below the $q$ percentile. ${ }^{23}$ In the fourth and final policy scenario, we further assume that the subsidy is directed to finance the fixed investment cost (e.g. education) required to access to the project with higher expected returns. More precisely, in this policy scenario we assume that all households whose income is below the median receive an investment subsidy, sufficient to cover the cost $I .^{24}$

The 4 th and 5th row in Table 4 report the results of the last two policy scenarios. Both policies raise long-run aggregate income much more than to government consumption, and they effectively reduce inequality. In particular, the income subsidy policy achieves the strongest decrease in the post-tax Gini, whereas the investment subsidy policy produces

\footnotetext{
${ }^{23}$ Disposable income will thus be equal to $\left(1-\tau\left(Y_{i t}\right)\right) p_{Q} Q_{i t}+s\left(Y_{i t}\right)$ for households whose market income is lower or equal to the $q$ percentile of the income distribution and it will be equal to $\left(1-\tau\left(Y_{i t}\right)\right) p_{Q} Q_{i t}$ for the remaining households.

${ }^{24}$ In case public resources are not enough to finance the investment cost for all agents below the median, the government distributes the subsidy solely to the poorest within this group, i.e. the bottom $25 \%$.
} 
the strongest decrease in the pre-tax Gini. The stronger impact on aggregate output is explained by the fact that, differently from government consumption, both subsidy policies target the households with low incomes, which have higher average propensity to consume and are more likely to be credit rationed. Furthermore, differently from a sheer income subsidy, the investment subsidy focuses on the main reason of income differences in our model, i.e. the asymmetric access to investment projects (or education) delivering higher labor productivity gains. It follows that such a policy will have not only a beneficial effect on the natural growth rate (and thus on the long-run level of income), but it will also reduce market-generated income inequality.

So far we have considered scenarios where policies were active since the beginning of the simulation, i.e. starting from a situation where the income distribution is fairly egalitarian. In the final battery of policy simulation experiments, we introduce the policy at different time steps, namely $t_{a}$ and $t_{b}$ with $t_{b}>t_{a} \cdot{ }^{25}$ We then analyse whether the policy measures decrease inequality once it has emerged. We exclude from our analysis the proportional taxation regime, since, as expected, this was not effective even if introduced from the start. Such policy experiments shed light on the role of timing and effectiveness of policy responses, in particular with respect to inequality. ${ }^{26}$

The results of the foregoing experiments are reported in Table 5. We find that the introduction of a progressive tax scheme that finances government consumption must be timely in order to be effective in reducing inequality. In contrast, a progressive tax on incomes that finances income subsidies to the bottom of the income distribution significantly decreases post-tax Gini inequality regardless of the time of implementation. Finally, a policy entailing a progressive taxation scheme that subsidizes the investment cost is effective in reducing both pre- and post-tax Gini index only if it is timely introduced at time $t_{a}$. Similarly to the government consumption policy, there is a window of opportunity that has to be caught, and after $t_{b}$ the investment subsidy policy is no longer effective in

\footnotetext{
${ }^{25}$ In this exercise $t_{a}$ corresponds to $20 \%$ of the total simulation time span and $t_{b}$ to $95 \%$.

${ }^{26}$ This analysis enters in the discussion about the policy inertia, which has been characteristic of the Eurozone, as opposed to the US, in which policy reactions have typically been more timely and bold. This difference in the timing of policy responses also explains why the effects of the Great Recession have been in some aspects less dramatic in the US than in the Eurozone, as documented by Fitoussi and Saraceno (2010).
} 


\begin{tabular}{llcc}
\hline Policy Scenario & Y & Pre-tax Gini & Post-tax Gini \\
\hline Benchmark Scenario & 1 & 1 & 1 \\
\hline Govt. consumption with progressive tax from $t_{a}$ & $1.010^{* *}$ & $1.012^{*}$ & 0.992 \\
Govt. consumption with progressive tax from $t_{b}$ & $1.004^{* *}$ & $1.010^{*}$ & 1.000 \\
\hline Income subsidy with progressive tax from $t_{a}$ & $1.008^{* *}$ & 1.007 & $0.754^{* *}$ \\
Income subsidy with progressive tax from $t_{b}$ & $1.004^{* *}$ & 1.003 & $0.876^{* *}$ \\
\hline Investment subsidy with progressive tax from $t_{a}$ & $1.019^{* *}$ & $0.830^{* *}$ & $0.793^{* *}$ \\
Investment subsidy with progressive tax from $t_{b}$ & $1.004^{* *}$ & 1.005 & 0.995 \\
\hline
\end{tabular}

Table 5: Aggregate income and inequality indicators in different policy scenarios with varying timing. Statistics are mean values over the last 500 periods and over $50 \mathrm{MC}$ repetitions. All statistics are reported in relation to benchmark scenario. Significance difference wrt. benchmark at $1 \%(* *)$ and $5 \%$ level $(*) .{ }^{28}$

reducing inequality. ${ }^{27}$ This outcome is explained by the cumulative character of household income dynamics in our model, where the income growth is proportional to that of the previous generation (cf. Section 3.2). Clearly, this implies that income asymmetries and inequality will widen over time and policy ought to be introduced as soon as possible to be effective. Finally, policies always improve long-run aggregate income no matter when they are introduced, but they have a stronger impact if they are introduced earlier.

\section{Concluding remarks}

We have developed a minimalist model to study how inequality can endogenously emerge in a world characterised by credit constraints and coordination failures, and how such disparities trigger lower social mobility and lower aggregate economic activity. A novel feature of our model is that household income dynamics is not only affected by supply-side constraints implying asymmetric access to education investment opportunities, but it is also constrained by the effective demand in the market for final goods.

The model shows that natural growth - i.e. a growth process implying that all pro-

\footnotetext{
${ }^{27}$ If after $t_{b}$ we combine the investment subsidy policy with progressive taxation with a higher top tax (of $30 \%$ instead of $15 \%$ ) on the richest $25 \%$ of households we obtain only a slight reduction in Post-tax Gini (of $2 \%$ ), but not in Pre-tax Gini.

${ }^{28}$ Emerging values of Gini coefficients are realistic and are ranging between 0.4933 and 0.5943 for market income, between 0.4481 and 0.5943 for net disposable income, with the upper bound being equal because related to the benchmark scenario with no redistributive policy. All values are available upon request.
} 
duction factors are fully employed - can be achieved only if income is appropriately redistributed towards the poorer households, which have high average propensity to consume. Moreover, as income dynamics depends on the state of the economy, redistributing income towards the poor does not only create the conditions for natural growth, but it also triggers a positive consumption externality which positively affects the income growth of all households.

Simulation results show that our model is able to jointly match several stylized facts on income inequality and social mobility by endogenously generating realistic levels of concentration, by producing income growth patterns that resemble the upper part of the Elephant curve (Milanovic, 2016), and by replicating the Great Gatsby curve (Corak, 2013). We have also tested the impact of several balanced-budget redistributive fiscal policies. Our policy experiments suggest that progressive taxation regimes reduce inequality and increase aggregate income and this is even more so when the progressivity of the tax scheme is coupled with subsidies targeting low-income households. Moreover, the timing of policy is relevant: fiscal policies that are implemented too late may have no significant effects on inequality.

Overall, our results dismiss the trickle-down narrative. Higher inequality does not boost social mobility. On the contrary, it hampers aggregate and personal income growth. Redistributing income towards the poor and facilitating their access to consumption and investment financing has instead the opposite effect of raising income growth which then also trickles up to wealthier strands of the society.

The model could be extended in two directions. First, one could introduce capital accumulation, which would then allow one to study also the dynamics of wealth inequality, e.g. along the lines proposed in Piketty (2014). Second, the introduction of imperfect competition in the goods markets would allow to analyze how market concentration may impact on the evolution of income inequality over time.

\section{Acknowledgments}

This paper has received financial support by the European Union Horizon 2020 Research and Innovation programme under grant agreement No. 822781 (GROWINPRO). We thank Giovanni 
Dosi, Emanuele Russo, Mattia Guerini, Francesco Lamperti, Luca Riccetti, Marco Ranaldi, Roberto Iacono, Martina Occelli along with several participants at the 6th World Congress of the International Microsimulation Association, the 24th Annual Workshop on Economic Science with Heterogeneous Interacting Agents, and the 31th Annual European Association for Evolutionary Political Economy Conference for useful comments.

\section{Bibliography}

Aghion, P., Banerjee, A., and Piketty, T. (1999). Dualism and macroeconomic volatility. The Quarterly Journal of Economics, 114(4):1359-1397.

Aghion, P. and Bolton, P. (1997). A theory of trickle-down growth and development. The Review of Economic Studies, 64(2):151-172.

Alvaredo, F., Chancel, L., Piketty, T., Saez, E., and Zucman, G. (2018). World Inequality Report 2018. Cambridge, MA: Harvard Univ. Press. Data downloaded in January 2020.

Aversi, R., Dosi, G., Fagiolo, G., Meacci, M., and Olivetti, C. (1999). Demand dynamics with socially evolving preferences. Industrial and Corporate Change, 8(2):353-408.

Axtell, R. (2006). Multi-agent systems macro: A prospectus. in: Post Walrasian macroeconomics: Beyond the dynamic stochastic general equilibrium model. DC Colander.

Banerjee, A. V. and Newman, A. F. (1993). Occupational choice and the process of development. Journal of Political Economy, 101(2):274-298.

Becker, G. S. and Tomes, N. (1979). An equilibrium theory of the distribution of income and intergenerational mobility. Journal of Political Economy, 87(6):1153-1189.

Becker, G. S. and Tomes, N. (1986). Human capital and the rise and fall of families. Journal of Labor Economics, 4(3, Part 2):S1-S39.

Berg, A., Ostry, J. D., Tsangarides, C. G., and Yakhshilikov, Y. (2018). Redistribution, inequality, and growth: new evidence. Journal of Economic Growth, 23(3):259-305.

Bernanke, B. S., Gertler, M., and Gilchrist, S. (1999). The financial accelerator in a quantitative business cycle framework. Handbook of macroeconomics, 1:1341-1393.

Bertrand, M. and Morse, A. (2016). Trickle-down consumption. Review of Economics and Statistics, 98(5):863-879.

Blanchard, O. J. and Kiyotaki, N. (1987). Monopolistic competition and the effects of aggregate demand. The American Economic Review, pages 647-666.

Botta, A., Caverzasi, E., Russo, A., Gallegati, M., and Stiglitz, J. E. (2019). Inequality and finance in a rent economy. Journal of Economic Behavior $\&$ Organization.

Bozio, A., Emmerson, C., O'Dea, C., and Tetlow, G. (2011). Do the rich really save more? Evidence from lifetime earnings and consumption data in the United Kingdom. London, United Kingdom: Institute for Fiscal Studies.

Brown, C. (2004). Does income distribution matter for effective demand? Evidence from the United States. Review of Political Economy, 16(3):291-307. 
Brunori, P., Ferreira, F. H., and Peragine, V. (2013). Inequality of opportunity, income inequality, and economic mobility: Some international comparisons. In Getting development right, pages $85-115$. Springer.

Bunn, P., Le Roux, J., Reinold, K., and Surico, P. (2018). The consumption response to positive and negative income shocks. Journal of Monetary Economics, 96:1-15.

Caiani, A., Russo, A., and Gallegati, M. (2019). Does inequality hamper innovation and growth? An AB-SFC analysis. Journal of Evolutionary Economics, 29(1):177-228.

Cardaci, A. (2018). Inequality, household debt and financial instability: An agent-based perspective. Journal of Economic Behavior \& Organization, 149:434-458.

Cardaci, A. and Saraceno, F. (2019). Between scylla and charybdis: income distribution, consumer credit, and business cycles. Economic Inquiry, 57(2):953-971.

Carvalho, L. and Rezai, A. (2015). Personal income inequality and aggregate demand. Cambridge Journal of Economics, 40(2):491-505.

Caucutt, E. M. and Lochner, L. (2020). Early and late human capital investments, borrowing constraints, and the family. Journal of Political Economy, 128(3):1065-1147.

Champernowne, D. G. (1953). A model of income distribution. The Economic Journal, $63(250): 318-351$.

Chetty, R., Hendren, N., Kline, P., Saez, E., and Turner, N. (2014). Is the United States still a land of opportunity? Recent trends in intergenerational mobility. American Economic Review, 104(5):141-47.

Ciarli, T., Lorentz, A., Savona, M., and Valente, M. (2012). The role of technology, organisation, and demand in growth and income distribution. Technical report, LEM Working Paper Series.

Cingano, F. (2014). Trends in income inequality and its impact on economic growth.

Clauset, A., Shalizi, C. R., and Newman, M. E. (2009). Power-law distributions in empirical data. SIAM review, 51(4):661-703.

Clementi, F. and Gallegati, M. (2005). Power law tails in the Italian personal income distribution. Physica A: statistical mechanics and its applications, 350(2-4):427-438.

Clower, R. and Leijonhufvud, A. (1975). The coordination of economic activities: a Keynesian perspective. The American Economic Review, 65(2):182-188.

Corak, M. (2013). Income inequality, equality of opportunity, and intergenerational mobility. Journal of Economic Perspectives, 27(3):79-102.

Corak, M. and Heisz, A. (1999). The intergenerational earnings and income mobility of Canadian men: Evidence from longitudinal income tax data. Journal of Human Resources, pages 504533.

Dabla-Norris, M. E., Kochhar, M. K., Suphaphiphat, M. N., Ricka, M. F., and Tsounta, E. (2015). Causes and consequences of income inequality: A global perspective. International Monetary Fund.

Dawid, H. and Gatti, D. D. (2018). Agent-based macroeconomics. Handbook of computational economics, 4:63-156. 
Diamond, P. A. (1982). Aggregate demand management in search equilibrium. Journal of Political Economy, 90(5):881-894.

Domar, E. D. (1946). Capital expansion, rate of growth, and employment. Econometrica, Journal of the Econometric Society, pages 137-147.

Dosi, G., Fagiolo, G., Napoletano, M., and Roventini, A. (2013). Income distribution, credit and fiscal policies in an agent-based Keynesian model. Journal of Economic Dynamics and Control, 37(8):1598-1625.

Dosi, G., Pereira, M. C., Roventini, A., and Virgillito, M. E. (2017a). The effects of labour market reforms upon unemployment and income inequalities: an agent-based model. SocioEconomic Review, 16(4):687-720.

Dosi, G., Pereira, M. C., Roventini, A., and Virgillito, M. E. (2017b). When more flexibility yields more fragility: the microfoundations of Keynesian aggregate unemployment. Journal of Economic Dynamics and Control, 81:162-186.

Dosi, G. and Roventini, A. (2017). Agent-based macroeconomics and classical political economy: some Italian roots. Italian Economic Journal, 3(3):261-283.

Dosi, G. and Roventini, A. (2019). More is different... and complex! the case for agent-based macroeconomics. Journal of Evolutionary Economics, 29(1):1-37.

Duesenberry, J. S. et al. (1949). Income, saving, and the theory of consumer behavior.

Dynan, K. E., Skinner, J., and Zeldes, S. P. (2004). Do the rich save more? Journal of Political Economy, 112(2):397-444.

Fagiolo, G., Guerini, M., Lamperti, F., Moneta, A., and Roventini, A. (2019). Validation of agent-based models in economics and finance. In Computer simulation validation, pages 763787. Springer.

Fagiolo, G. and Roventini, A. (2017). Macroeconomic Policy in DSGE and Agent-Based Models Redux: New Developments and Challenges Ahead. Journal of Artificial Societies \&s Social Simulation, 20(1).

Fitoussi, J. P. and Saraceno, F. (2010). Europe: how deep is a crisis? Policy responses and structural factors behind diverging performances. Journal of Globalization and development, $1(1)$.

Fitoussi, J.-P., Saraceno, F., et al. (2011). Inequality, the crisis and after. Rivista di Politica Economica, (1):9-27.

Gabaix, X., Lasry, J.-M., Lions, P.-L., and Moll, B. (2016). The dynamics of inequality. Econometrica, 84(6):2071-2111.

Gaffard, J.-L., Napoletano, M., et al. (2012). Agent-based models and economic policy. Ofce.

Galor, O. and Zeira, J. (1993). Income distribution and macroeconomics. The Review of Economic Studies, 60(1):35-52.

Gibrat, R. (1931). Les inégalits économiques. Sirey.

Güell, M., Pellizzari, M., Pica, G., and Rodríguez Mora, J. V. (2018). Correlating social mobility and economic outcomes. The Economic Journal, 128(612):F353-F403. 
Guerini, M., Napoletano, M., and Roventini, A. (2018). No man is an island: The impact of heterogeneity and local interactions on macroeconomic dynamics. Economic Modelling, 68:82-95.

Guven, C. and Sørensen, B. E. (2012). Subjective well-being: Keeping up with the perception of the Joneses. Social Indicators Research, 109(3):439-469.

Halter, D., Oechslin, M., and Zweimüller, J. (2014). Inequality and growth: the neglected time dimension. Journal of Economic Growth, 19(1):81-104.

Harrod, R. F. (1939). An essay in dynamic theory. The economic journal, 49(193):14-33.

Howitt, P. and Clower, R. (2000). The emergence of economic organization. Journal of Economic Behavior $\&$ Organization, 41(1):55-84.

Jaffee, D. and Stiglitz, J. (1990). Credit rationing. Handbook of monetary economics, 2:837-888.

Jappelli, T. and Pistaferri, L. (2014). Fiscal policy and MPC heterogeneity. American Economic Journal: Macroeconomics, 6(4):107-36.

Jaumotte, F. and Osorio Buitron, C. (2020). Inequality: traditional drivers and the role of union power. Oxford Economic Papers, 72(1):25-58.

Jenkins, S. P. (2017). Pareto models, top incomes and recent trends in UK income inequality. Economica, 84(334):261-289.

Kaldor, N. (1955). Alternative theories of distribution. The Review of Economic Studies, 23(2):83-100.

Keynes, J. M. (1936). The general theory of employment, interest, and money. Pelgrave Macmillan.

Krueger, A. B. (2012). The rise and consequences of inequality in the United States. Speech at the Center for American Progress, 12.

Krueger, D., Mitman, K., and Perri, F. (2016). Macroeconomics and household heterogeneity. In Handbook of Macroeconomics, volume 2, pages 843-921. Elsevier.

Lakner, C. and Milanovic, B. (2013). Global income distribution: From the fall of the Berlin Wall to the Great Recession. The World Bank.

Lavoie, M. (2003). A primer on endogenous credit-money. Modern Theories of Money, pages $506-543$.

Mazumder, B. (2005). The apple falls even closer to the tree than we thought. Unequal chances: Family background and economic success, pages 80-99.

McLeay, M., Amar, R., and Thomas, R. (2014). Money creation in the modern economy, Bank of England's Monetary analysis directorate. Quarterly Bulletin Q1.

Mian, A. R., Straub, L., and Sufi, A. (2020). Indebted demand. Technical report, National Bureau of Economic Research.

Milanovic, B. (2016). Global inequality: A new approach for the age of globalization. Harvard University Press. 
Morelli, S. and Atkinson, A. B. (2015). Inequality and crises revisited. Economia Politica, $32(1): 31-51$.

Murugasu, D., Wei, A. J., and Hwa, T. B. (2013). Marginal propensity to consume across household income groups. Bank Negara Malaysia, Working Paper No. WP2.

Norris, J. R. (1998). Markov chains. Number 2. Cambridge University Press.

OECD (2018). A Broken Social Elevator?: How to Promote Social Mobility. OECD.

Ostry, J. D., Berg, A., et al. (2011). Inequality and unsustainable growth; two sides of the same coin? Technical report, International Monetary Fund.

Ostry, M. J. D., Berg, M. A., and Tsangarides, M. C. G. (2014). Redistribution, inequality, and growth. Technical Report 14/02, International Monetary Fund Staff Papers.

Palagi, E., Napoletano, M., Roventini, A., and Gaffard, J.-L. (2017). Inequality, redistributive policies and multiplier dynamics in an agent-based model with credit rationing. Italian Economic Journal, 3(3):367-387.

Pasinetti, L. L. (1962). Rate of profit and income distribution in relation to the rate of economic growth. The Review of Economic Studies, 29(4):267-279.

Perugini, C., Hölscher, J., and Collie, S. (2015). Inequality, credit and financial crises. Cambridge Journal of Economics, 40(1):227-257.

Piketty, T. (1997). The dynamics of the wealth distribution and the interest rate with credit rationing. The Review of Economic Studies, 64(2):173-189.

Piketty, T. (2014). Capital in the 21st Century. Harvard University Press Cambridge, MA.

Piketty, T., Saez, E., and Stantcheva, S. (2014). Optimal taxation of top labor incomes: A tale of three elasticities. American Economic Journal: Economic Policy, 6(1):230-71.

Piketty, T., Saez, E., and Zucman, G. (2017). Distributional national accounts: methods and estimates for the United States. The Quarterly Journal of Economics, 133(2):553-609.

Pressman, S. (1997). Consumption, income distribution and taxation: Keynes' fiscal policy. Journal of Income Distribution, 7(1):29-44.

Quah, D. T. (1996). Twin peaks: growth and convergence in models of distribution dynamics. The Economic Journal, 106(437):1045-1055.

Rajan, R. G. (2018). Fault lines-how hidden fractures still threaten the World Economy, ISBN: 978-93-5029-173-3. Journal of Business Thought, 6:137-139.

Rengs, B. and Scholz-Wäckerle, M. (2019). Consumption \& class in evolutionary macroeconomics. Journal of Evolutionary Economics, 29(1):229-263.

Roine, J., Vlachos, J., and Waldenström, D. (2009). The long-run determinants of inequality: What can we learn from top income data? Journal of Public Economics, 93(7-8):974-988.

Russo, A. (2017). An agent based macroeconomic model with social classes and endogenous crises. Italian Economic Journal, 3(3):285-306. 
Russo, A., Riccetti, L., and Gallegati, M. (2016). Increasing inequality, consumer credit and financial fragility in an agent based macroeconomic model. Journal of Evolutionary Economics, $26(1): 25-47$.

Solow, R. M. (1956). A contribution to the theory of economic growth. The Quarterly Journal of Economics, 70(1):65-94.

Späth, J. and Schmid, K. D. (2018). The distribution of household savings in Germany. Jahrbücher für Nationalökonomie und Statistik, 238(1):3-32.

Stiglitz, J. E. (2012). The price of inequality: How today's divided society endangers our future. WW Norton \& Company.

Stiglitz, J. E. (2015). New theoretical perspectives on the distribution of income and wealth among individuals: Part II: Equilibrium wealth distributions. Technical report, National Bureau of Economic Research.

Veblen, T. (1899). The theory of the leisure class. (Republished, 1934, by New York: Modern library). 


\section{Appendix}

\section{A Model}

\section{A.1 Household investment decisions}

As indicated by Equation (4) planned expenditures of a household depend on the decision to pay the fixed investment cost $I$ or not. However, under quite general conditions on the expected value of the labor efficiency shocks, a risk-neutral household will always have the incentive to undertake the fixed investment in our model. This can be shown in an expected utility framework. More precisely, following the works by Galor and Zeira (1993), Aghion and Bolton (1997) and Piketty (1997) let denote by $U\left(C_{i t}, W_{i t+1}\right)$ the utility of a household, which is an increasing function of actual consumption $C_{i t}$ (which can be different from desired consumption as we saw in the paper) and of the bequest $W_{i t+1}$.

Moreover, denote by $W_{i t+1}^{I}$ household $i$ 's end-of-period wealth if the household pays the fixed investment, and by $W_{i t+1}^{N I}$ her end-of-period wealth if she does not pay such a cost.

Household $i$ will pay the fixed investment if the expected utility from paying the fixed investment is higher, that is:

$$
E U\left(C_{i t}, W_{i t+1}^{I}\right) \geq E U\left(C_{i t}, W_{i t+1}^{N I}\right)
$$

The assumption of risk-neutrality implies that the utility function $U\left(C_{i t}, W_{i t+1}\right)$ is linear. ${ }^{29}$ Accordingly, condition (32) can be restated as:

$$
U\left(C_{i t}, E\left(W_{i t+1}^{I}\right)\right) \geq U\left(C_{i t}, E\left(W_{i t+1}^{N I}\right)\right)
$$

which indicates that a household will undertake the fixed investment if it returns a higher endof-period wealth in expected terms.

The level of expected wealth will be different depending on whether the household is a borrower or a saver. Let's start with borrowers first. Recall that the income of a household (without taxes) is equal to $p_{Q} Q_{i t}$. The expected end-of-period wealth of a borrower who pays the fixed investment cost is:

$$
E\left(W_{i t+1}^{I}\right)=A_{i t-1}\left(1+\mu_{2}\right)+\left(W_{i t}-C_{i t}-I\right)\left(1+r^{b}\right)
$$

and it is instead equal to:

$$
E\left(W_{i t+1}^{N I}\right)=A_{i t-1}\left(1+\mu_{1}\right)+\left(W_{i t}-C_{i t}\right)\left(1+r^{b}\right)
$$

without investment. The expected wealth of a borrower will be higher with the fixed investment if:

$$
\mu_{2}-\mu_{1} \geq \frac{I}{A_{i t-1}} \cdot\left(1+r^{b}\right)
$$

given that $A_{i t-1} \geq 1 \quad \forall t$ it follows that a sufficient condition to provide the incentive to undertake the fixed investment is:

$$
\mu_{2}-\mu_{1} \geq I \cdot\left(1+r^{b}\right)
$$

The above condition is also sufficient to provide the incentive to savers to undertake the

\footnotetext{
${ }^{29}$ Assuming that households are risk averse would have not changed the final results. This is because we assumed that the distributions of the labor efficiency shocks have the same standard deviation. Thus, the two alternatives (investment or not investment) have the same certainty equivalent.
} 
fixed investment. Indeed, a saver will undertake the investment if:

$$
\mu_{2}-\mu_{1} \geq \frac{I}{A_{i t-1}} \cdot\left(1+r^{s}\right)
$$

Given that $r^{b}>r^{s}$ condition (37) is also sufficient to provide savers the incentive to undertake the fixed investment.

\section{A.2 The bank balance sheet}

The representative bank's total credit supply, $T S_{t}$ is:

$$
T S_{t}=\sum_{i=1}^{N} l_{i t}^{a},
$$

where the actual loan, $l_{i t}^{a}$, granted to a borrower $i$ by the bank is given by the minimum between the maximux allotable credit $l_{i t}^{\max }$ (see Equation (6)) and credit demand $C D_{i t}$ (cf. Equation $(5))$.

$$
l_{i t}^{a c t u a l}=\min \left\{l_{i t}^{\max }, \max \left(C D_{i t}, 0\right)\right\} .
$$

We assume an endogenous money framework (see e.g. Lavoie, 2003, McLeay et al., 2014). Thus, the bank opens up a new deposit whenever it grants a new loan to a borrower. Bank liabilities, $L_{t}^{B}$, are defined as the difference between the bank's assets (the credit supply, $T S_{t}$ ) and its net worth, $E_{t}^{B}$ :

$$
L_{t}^{B}=T S_{t}-E_{t}^{B}
$$

Bank's profits $\pi_{t}^{B}$ are equal to:

$$
\pi_{t}^{B}=r\left(1+\mu^{b}\right) T S_{t}-r\left(1-\mu^{s}\right) D_{t}
$$

where $D_{t}$ are savers' deposits. Notice that only savers' deposits are remunerated. The deposits open as a part of the lending activity give no remuneration (and they thus have a cost of zero for the bank).

Whenever a borrower goes bankrupt, her bad debt, $B D_{i t}$, negatively affects the bank's net worth.

We assume that there is a target level of net worth $\bar{E}_{t}^{B}$ such that if $E_{t}^{B} \geq \bar{E}_{t}^{B}$ bank profits are distributed to a homogeneous class of agents, the bankers, who entirely consume their income. If instead $E_{t}^{B}<\bar{E}_{t}^{B}$ then the bank does not distribute the profits. The law of motion for the bank's net-worth is thus:

$$
E_{t}^{B}= \begin{cases}E_{t-1}^{B}-\Sigma_{i=1}^{N} B D_{i t}, & \text { if } E_{t}^{B} \geq \bar{E}_{t}^{B} \\ E_{t-1}^{B}+\pi_{t}^{B}-\Sigma_{i=1}^{N} B D_{i t}, & \text { if } E_{t}^{B}<\bar{E}_{t}^{B}\end{cases}
$$




\section{B Parameter values and initial conditions in simula- tion analyses}

Table (6) below all parameters used to obtain the simulation results discussed in Section 4.

\begin{tabular}{lcc}
\hline Description & Symbol & Value \\
\hline Montecarlo replications & $\mathrm{MC}$ & 50 \\
Time sample & $\mathrm{T}$ & 5000 \\
Number of agents & $\mathrm{N}$ & 1000 \\
Expected value of low productivity project distribution & $\mu_{1}$ & 0.01 \\
Expected value of high productivity project distribution & $\mu_{2}$ & 0.011 \\
Standard deviation of project distributions & $\sigma$ & 0.0115 \\
Weight for social component in consumption rule & $\delta$ & 0.05 \\
Coefficient consumption rule & $\epsilon$ & 0.9 \\
Expected value of idiosyncratic constant consumption rule & $\mu_{k}$ & 30 \\
St. dev. of idiosyncratic constant consumption rule & $\sigma_{k}$ & 15 \\
Sample of consumption friends size & $\mathrm{n}$ & 50 \\
Loan-to-value ratio & $\rho$ & 0.5 \\
Investment cost & $\mathrm{I}$ & 1 \\
Central bank interest rate & $\mathrm{r}$ & 0.01 \\
Lending rate mark-up & $\mu_{b}$ & 0.5 \\
Deposit mark-down & $\mu_{s}$ & 0.1 \\
Bottom \% threshold for eligibility for subsidy & $q$ & 50 \\
\hline Proportional tax rate & $\tau_{\text {prop }}$ & 0.1 \\
Progressive tax rates & $\tau_{\text {prog } 1}$ & 0.01 \\
& $\tau_{\text {prog } 2}$ & 0.05 \\
& $\tau_{\text {prog } 3}$ & 0.1 \\
& $\tau_{\text {prog }}$ & 0.15 \\
\hline
\end{tabular}

Table 6: Parameters

All simulation results are averages over 50 independent Monte-Carlo iterations. Each iteration is composed of 5000 time steps. To focus only on the long-run statistical properties we compute averages by considering only the last 500 periods of each iteration. In fact, in the analysis we start considering periods just after the transient phase is concluded, in line with the agent-based methodology guidelines (Fagiolo and Roventini, 2017).

For initializing our simulations we assume a quite egalitarian economy. We draw initial potential incomes randomly in order to get an initial Gini coefficient of around 0.1. A household's initial wealth is initialized as equal to the household's potential income. Moreover, initial consumption is equal to the household's desired consumption and the first productivity shocks are drawn from the same low-productivity distribution for all households, with expected value equal to $\mu_{1}$. In the initial conditions the economy starts in a situation of equality between actual and potential income.

At the beginning of the simulation we also randomly draw the group of reference in consumption decisions, which is household-specific. In our baseline exercises $\bar{C}_{i t-1}^{\text {group }}$ will be calculated on 50 agents for each household and the network of social relations will be kept fixed from the beginning throughout the simulation. 


\section{ABOUT OFCE}

The Paris-based Observatoire français des conjonctures économiques (OFCE), or French Economic Observatory is an independent and publicly-funded centre whose activities focus on economic research, forecasting and the evaluation of public policy.

Its 1981 founding charter established it as part of the French Fondation nationale des sciences politiques (Sciences Po), and gave it the mission is to "ensure that the fruits of scientific rigour and academic independence serve the public debate about the economy". The OFCE fulfils this mission by conducting theoretical and empirical studies, taking part in international scientific networks, and assuring a regular presence in the media through close cooperation with the French and European public authorities. The work of the OFCE covers most fields of economic analysis, from macroeconomics, growth, social welfare programmes, taxation and employment policy to sustainable development, competition, innovation and regulatory affairs.

\section{ABOUT SCIENCES PO}

Sciences $\mathrm{Po}$ is an institution of higher education and research in the humanities and social sciences. Its work in law, economics, history, political science and sociology is pursued through ten research units and several crosscutting programmes.

Its research community includes over two hundred twenty members and three hundred fifty PhD candidates. Recognized internationally, their work covers a wide range of topics including education, democracies, urban development, globalization and public health.

One of Sciences Po's key objectives is to make a significant contribution to methodological, epistemological and theoretical advances in the humanities and social sciences. Sciences Po's mission is also to share the results of its research with the international research community, students, and more broadly, society as a whole.

\section{SciencesPo}

